THREATENED OR THREATENING? THE FRAMING OF ASYLUM SEEKERS FROM THE UNITED STATES IN THE CANADIAN NEWSPRINT MEDIA

by

Ana Brdjanin, BA, Wilfrid Laurier University, 2016

\author{
A Major Research Paper \\ presented to Ryerson University \\ in partial fulfillment of the requirements for the degree of \\ Master of Arts \\ in the program of \\ Immigration and Settlement Studies
}

Toronto, Ontario, Canada, 2017

(C) Ana Brdjanin 2017 


\section{AUTHOR'S DECLARATION FOR ELECTRONIC SUBMISSION OF A MAJOR RESEARCH PAPER (MRP)}

I hereby declare that I am the sole author of this Major Research Paper. This is a true copy of the MRP, including any required final revisions.

I authorize Ryerson University to lend this MRP to other institutions or individuals for the purpose of scholarly research

I further authorize Ryerson University to reproduce this MRP by photocopying or by other means, in total or in part, at the request of other institutions or individuals for the purpose of scholarly research.

I understand that my MRP may be made electronically available to the public.

Ana Brdjanin 


\title{
THREATENED OR THREATENING? THE FRAMING OF ASYLUM SEEKERS FROM THE UNITED STATES IN THE CANADIAN NEWSPRINT MEDIA
}

\author{
Ana Brdjanin \\ Master of Arts 2017 \\ Immigration and Settlement Studies \\ Ryerson University
}

\begin{abstract}
Following the implementation of Donald Trump's Executive Order Protecting the Nation from Foreign Terrorist Entry into the United States, Canada has seen an increase in asylum seekers irregularly entering the country from the United States. The Canada-US Safe Third Country Agreement is viewed as the main factor why asylum seekers have been crossing irregularly rather than at official border crossings. This study examines how the Canadian newsprint media has been framing these asylum seekers by analyzing 83 articles published in the National Post and The Globe and Mail between January 27, 2017 and April 27, 2017. A directed content analysis and social constructionist lens revealed seven dominant framings of asylum seekers, with the 'victim/human rights' framing occurring most frequently. The results of this study show that asylum seekers are more frequently being framed positively than negatively, a likely result of Canadian attempts at national self-differentiation from a negatively-perceived America.
\end{abstract}

Keywords: Safe Third Country Agreement; Donald Trump; Asylum Seeker; Newsprint 


\section{ACKNOWLEDGEMENTS}

I would first like to thank my supervisor Dr. Idil Atak for her guidance, expertise, and support throughout this entire process. Her outstanding academic supervision allowed this paper to be my own work but also steered me in the right direction whenever needed.

I would also like to extend special thanks to Dr. Graham Hudson for his role as second reader. I am grateful for his valuable questions and comments which allowed me to consider aspects of my work in a new manner.

Finally, thank you to my family and friends who were there for me and encouraged me, even when I had my doubts. 


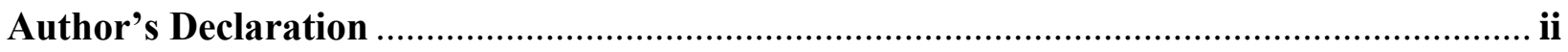

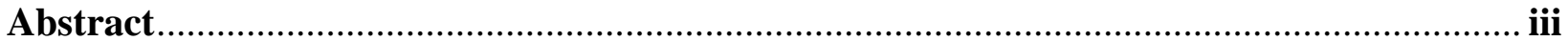

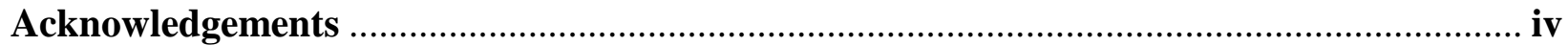

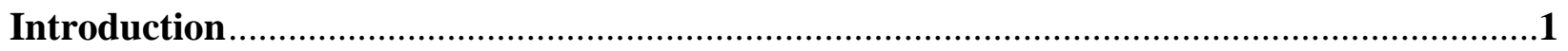

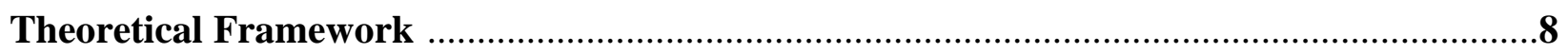

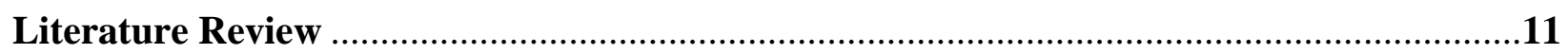

Theme 1: Negative Framing of Immigration in Canadian Newsprint Media ........................12

Theme 2: Academic Criticisms of the Canada-US Safe Third Country Agreement .................15

Theme 3: Canadian National Identity Formation ...........................................................17

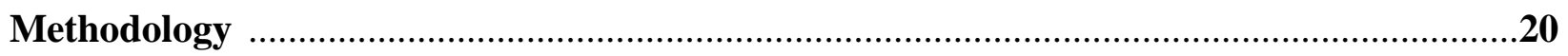

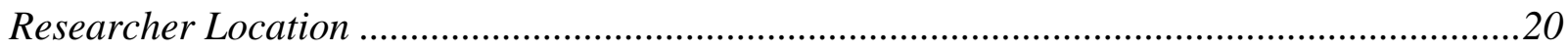

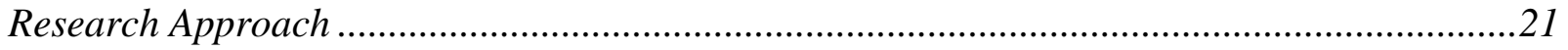

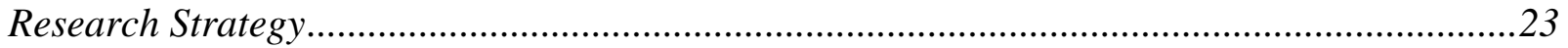

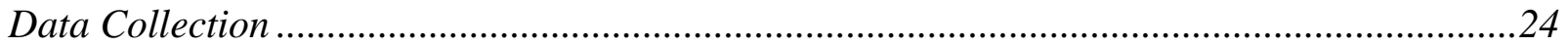

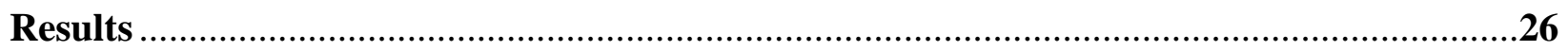

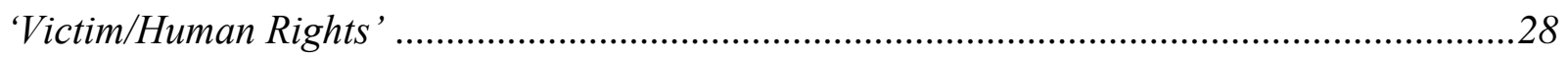

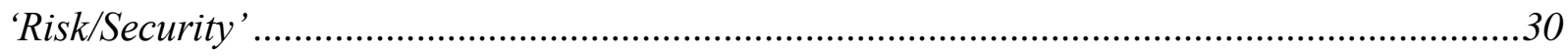

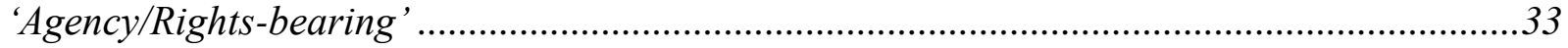

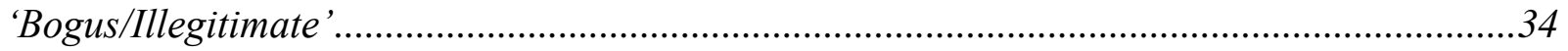

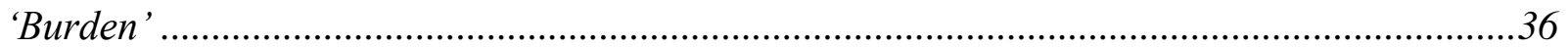

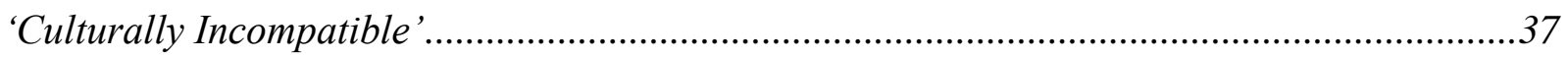

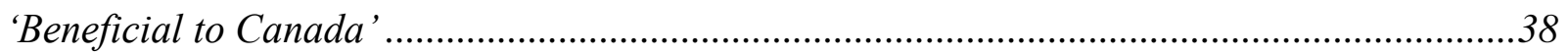

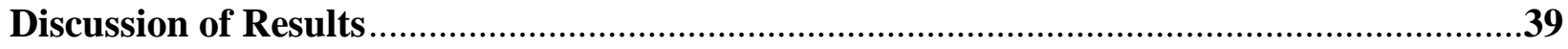

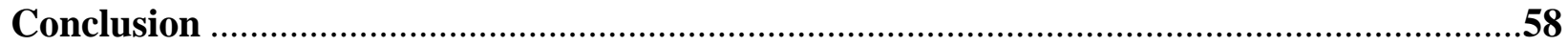

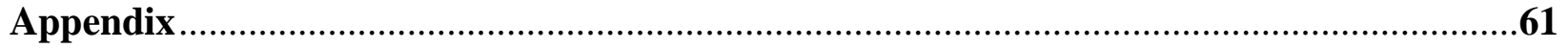

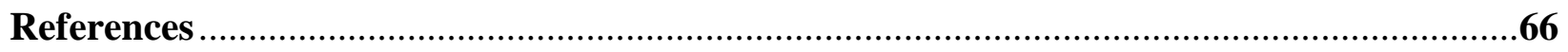




\section{Introduction}

During the course of Donald Trump's campaign for presidency, and especially in the time since his inauguration on January 20, 2017, his stance on immigration-related issues has dominated the media, and his administration's rhetoric surrounding immigration has been characterized by fear and discrimination. In particular, the Executive Order Protecting the Nation from Foreign Terrorist Entry into the United States, implemented on January 27, 2017, drew national and international criticism. This executive order barred nationals of seven Muslimmajority countries from temporarily entering the United States, and temporarily suspended all refugee admissions, with those from Syria suspended indefinitely (The White House, 2017). The Order sparked widespread concern about the ramifications it would have for those fleeing persecution, as they would no longer be able to claim asylum in the United States. The initial Executive Order resulted in dozens of lawsuits, and was ultimately halted by a federal judge, resulting in the signing of a revised version on March 6, 2017 (Zoppo \& Santos, 2017). This revised version banned entry into the United States for 90 days for citizens of the same Muslimmajority countries, with the exception of Iraq (Zoppo \& Santos, 2017). It experienced similar backlash as the first version did, and ended up being stopped by the courts prior to even being implemented (Zoppo \& Santos, 2017). Despite the public backlash and legal obstacles which faced the Executive Orders, they sparked an era of fear and uncertainty for asylum seekers in the United States, and produced the necessary conditions for the growth of xenophobia. This era has proven to continue over the months, as the ban was reinstated on June 26, 2017. Currently, it holds that, “...nationals from Syria, Iran, Yemen, Sudan, Libya, and Somalia will not be allowed to enter the country, unless they are granted a waiver of entry" which can only be obtained by showing a, “...credible claim of a bona fide relationship with a person or entity in the United 
States" (HILSC, 2017). The same conditions apply to refugees attempting to enter the United States (HILSC, 2017).

As is often the case, political developments in the United States have had very real ramifications for Canada. Since the implementation of Trump's executive order, asylum claims from individuals crossing the border irregularly from the United States have substantially increased (Canadian Council for Refugees, 2017). These asylum seekers are largely nationals of countries which fall under Trump's executive order, although some are from unaffected countries (Canadian Council for Refugees, 2017). Throughout the winter on 2017, there have consistently been reports of individuals travelling to the Canadian border in what were often subzero temperatures, leading to several instances of frostbite requiring amputation, and often with small children. Rather than a short-term increase in such arrivals in the immediate aftermath of Trump's Executive Order, irregular crossings from America into Canada have proven to continue. In June of 2017, 884 asylum seekers were intercepted by the RCMP after irregularly crossing into Canada, a number which has steadily been increasing in recent months (Government of Canada, 2017). The month of July saw more than 3,100 asylum seekers cross into Canada, with an additional 3,800 entering in the first half of August (Paperny \& Lampert, 2017). These figures affirm concerns which arose throughout the winter, that the number of asylum seekers would continue to increase as the winter came to an end and the weather grew warmer.

Canadians have been witnessing these events unfold, and unsurprisingly, there has been a strong media reaction to these developments in Canada. In addition to generally condemning the Trump administration for its discriminatory policies, much of the media attention has been on the Canada-US Safe Third Country Agreement (Government of Canada, 2002). The Agreement 
generally holds that Canada and the US are both safe countries for refugees, and that as such, individuals must claim asylum in the first of the two countries in which they arrive (Government of Canada, 2002). Therefore, if an individual were to enter from America into Canada (or vice versa) at a port of entry and make an asylum claim, he or she would be denied and returned to the other Party, "...territory where they could have found effective protection" (Government of Canada, 2002). The Agreement was initially established in an attempt to, “... enhance the international protection of refugees by promoting the orderly handling of asylum applications by the responsible party and the principle of burden-sharing" (Government of Canada, 2002). However, the Agreement only applies to individuals, “...making a refugee status claim at a land border port of entry" (Government of Canada, 2002 Article 1). This so-called 'loophole' in the Agreement means that asylum seekers from America can make a claim in Canada if they cross the border irregularly, i.e. at an unmarked border crossing. This is due to the fact that the Canadian Constitution holds that any person on Canadian soil has certain protections, including the right to due process and a fair hearing (Government of Canada, 2017).

The increase in asylum seekers crossing into Canada from the United States is a recent phenomenon, and as such, there is currently a lack of academic understanding and analysis of the way in which the issue is being framed by the media. The latest figures show that more than 3,800 asylum seekers crossed into Canada in the first half of August, which is in great contrast to the 315 asylum seekers which irregularly crossed into Canada in all of 2011 (Government of Canada, 2017). Furthermore, the current situation is unique because the Canadian and American governments are generating starkly opposing discourses on immigration-related issues, where previously they have been closer in line with one another. In Canada, the current Liberal government is employing a highly humanitarian approach towards asylum seekers and refugees, 
and generating positive discourses on issues such as religious, cultural and ethnic diversity. One of the main ways that this approach has been exemplified is through the resettlement of more 40,000 Syrian refugees to Canada. These discourses and resulting actions are in contrast both to the policies and discourses of the previous Harper government in Canada, and to the current Trump administration in the United States, which has attempted to indefinitely block the entry of Syrian refugees. Therefore, examining how the Canadian newsprint media has responded to the issue of asylum seekers irregularly coming into the country from the United States in a time of highly diverging discourses and policies provides valuable insight into the direction which Canadian public opinion may be heading.

As such, this study examines Canadian newsprint media's reactions to the increasing numbers of asylum seekers entering Canada irregularly in the context of Donald Trump's antiimmigrant policies and the Canada-US Safe Third Country Agreement, by asking; "How is the Canadian newsprint media framing the asylum-seekers crossing into Canada from the United States?" This question aims to first uncover the ways in which the Canadian newsprint media is constructing asylum seekers' identities. Depending on which aspects of the asylum seekers' journeys and resulting challenges the media chooses to focus on, and which aspects are omitted, their identities can be constructed in a multitude of different ways. The narrative that the newsprint media chooses to employ is highly influential, as it is circulated among the Canadian public day after day, and has the effect of either reinforcing existing perceptions of asylum seekers or altering them. Since the issue which is being examined is directly connected to developments taking place in the US, the way in which the newsprint media constructs asylum seekers' identities will also shed light on the ways that Canadians either relate to, or differentiate themselves from, Americans. If the constructions of asylum seekers' identities were in line with 
rhetoric about asylum seekers which is emerging from the United States, that would suggest a period of solidarity and similar opinions between the two countries. On the other hand, if asylum seekers' identities are constructed in ways which starkly oppose American rhetoric, that would suggest a period of diverging opinions in which the Canadian media is attempting to draw a differentiating line between the two countries.

The study consists of a directed content analysis of 83 newspaper articles drawn from Canada's two national newspapers, The Globe and Mail and the National Post, published between January 27, 2017 and April 27, 2017. The particular ways in which the asylum seekers entering Canada at unmarked border crossings are framed by the Canadian newsprint media are identified. Within the framings of asylum seekers, the newsprint media's framing of Canada and the Canadian government, and of the Canada-US Safe Third Country Agreement is also addressed. While this study found that seven distinct framings of asylum seekers are employed in the Canadian newsprint media, the general consensus in all of them is that the Canada-US Safe Third Country Agreement is no longer sufficiently serving its intended purposes. The “...orderly handling of asylum applications..." and the, “...principle of burden-sharing” are both eroded as asylum seekers increasingly enter Canada irregularly. Furthermore, the very premise on which the Agreement was formed, that Canada and the United States are both countries which offer effective protection to refugees, is brought into question by the Trump administration and its policies. Asylum seekers themselves, however, were found to be more frequently framed positively than negatively by the newsprint media. This positive framing is a potential result of Canadian attempts at self-differentiation from a negatively-perceived America, which allows for the perpetuation of Canadian national myths, and for the construction of a national identity in opposition to America and Americans. 
The newsprint media plays an important role in how the Canadian public understands controversial social and political issues such as immigration. In turn, these understandings and public discourses have the potential to impact immigration policy and various other government decisions. The way in which asylum seekers are framed by the media, for instance, can have a significant impact on the development of refugee policy. If refugees are presented in the media as desperate individuals fleeing unimaginable violence and human rights abuses, in search of safety for themselves and their families, an empathic response is often evoked from the population, along with a general support for humanitarian aid and relaxed border regulations (Sarbit, 2003). In contrast, representations of asylum seekers as 'queue jumpers' and economic migrants posing as refugees tend to evoke very different responses. Fear, anger, and calls for stricter immigration policy are just a few among many. An example of such a response took place in Canada in 1999, when four unmarked ships carrying 599 undocumented Fujianese nationals arrived at Canada's west coast. The negative manner in which these asylum seekers were portrayed by the media resulted in calls for immigration reform, and in Canada's immigration system being constructed as failing (Greenberg \& Hier, 2001).

Given the media's influence over the ways in which the general public conceptualizes refugees and asylum seekers, it is vital to understand dominant media representations of these individuals, in order to understand in which direction policy may be heading, and what can be done about it.

Media discourses of fear in a post-9/11 context, and of perceived abuse of refugee policy by supposed economic migrants, played a large role in the initial formulation and signing of the Canada-US Safe Third Country Agreement in 2002 (Cutler, 2004). Such discourses which presented asylum seekers in a negative light largely continued, and maybe even intensified, 
throughout Canada's Harper era, from 2006 to 2015. For years, the Harper government spread rhetoric of asylum seekers as 'bogus' and taking advantage of Canada (The Council of Canadians, 2014). During this time Canada's reputation of being a world leader in refugee resettlement and acceptance was eroded, and fewer numbers of refugees were admitted annually than in years prior to Harper's election (The Council of Canadians, 2014). Between 2006 and 2011, the total number of accepted refugee claims dropped by 25 percent, and 83,382 deportations were carried out (The Council of Canadians, 2014). The rights of the asylum seekers which were fortunate enough to be admitted into Canada were weakened as well, through measures such as bill C-43, which worked to restrict refugees' access to social assistance and health care (House of Commons, 2014).

Harper's negative political rhetoric about asylum seekers ultimately ended up contributing to him losing the federal election in 2015. The end of his second term as Prime Minister coincided with the Syrian refugee crisis, and a realization by the Canadian public and media outlets that Canada simply was not doing enough to help. Perhaps the most powerful factor which worked to discredit years of Harper's negative discourse about refugees and to evoke the sympathy of the Canadian people was the globally-circulated image of Alan Kurdi's tiny drowned body washed up on a Turkish beach. During this time, while there was a great amount of focus on refugees in the media, there was very little focus on the Canada-US Safe Third Country Agreement. This is due to the fact that the numbers of individuals crossing the border into Canada were at normal and manageable levels, whereas the refugees that the media was focusing on were those which were coming to Canada from overseas.

Now, 13 years later, with the Agreement under scrutiny due to political developments in the United States, it is vital to understand media discourses around it if we wish to understand in 
which direction Canada may be headed. This paper aims to provide insight into such an understanding, by examining current newsprint media framings of asylum seekers who are irregularly crossing into Canada. Furthermore, the way that asylum seekers are framed in the newsprint media also provides valuable insights about Canadian perceptions of the Trump administration, and about Canadian perceptions of itself as a society.

To adequately address the issue at hand, this paper will be divided into five main sections. The first section consists of a discussion of the broad theoretical framework orienting this paper, which is that of Social Constructionism (Berger \& Luckmann, 1966). The secondary guiding concept of 'Othering' (Said, 1978) will also be addressed. The second section, the Literature Review, will present dominant themes in existing academic literature related to the topic at hand, and explain how this study contributes to each of them. The third section, Methodology, will explain the specific ways in which this study was conducted. The fourth section will present the results of this study, including the framing of asylum seekers, of Canada, and of the Canada-US Safe Third Country Agreement. The fifth and final section consists of a discussion of these results, in which they will be explained and contextualized.

\section{Theoretical Framework}

The large theoretical framework which frames this research study is social constructionism (Berger \& Luckmann, 1966). Essentially, social constructionism holds that rather than having an objective and unchanging meaning, individuals and groups construct reality in a certain way, through social interactions (Berger \& Luckmann, 1966). As such, the theory departs from constructivist notions of universal truths and a single reality. Instead, it views relations between individuals and groups as contributing to the construction of multiple realities. Put differently, the social constructionist perspective holds that we never know what is 
universally true or false, what is good or bad, what is right or wrong; we know only stories about what is true, false, good, bad, right or wrong (Galbin, 2014). These 'stories' make up multiple realities about our social worlds, each of which are rooted in highly contextualized circumstances and consist of a multitude of individual factors and life experiences. The theory views speech and language as holding central roles in the creation of these multiple realities, as communication is key to our understandings of ourselves and the social worlds in which we live (Galbin, 2014).

This framework is relevant to the purposes of this study in two main ways. First, as a key form of national communication and knowledge creation, the newsprint media works to socially construct asylum seekers' identities. While political discourses are another major contributor to such constructions, this study focuses on the media framings and only considers political discourses surrounding refugees and asylum seekers in the extent to which they emerge in the analyzed newsprint media. These constructions in turn influence the ways in which asylum seekers are viewed and treated by the Canadian government, and the Canadian public. As such, the theory of social constructionism will be used to explore the current media discourses surrounding asylum seekers in Canada. According to past studies,

"Asylum seeker is now a term that is used unambiguously, and immediately conjures up cheat, liar, criminal, sponger - someone deserving of hostility by virtue not of any misdemeanor, but simply because he or she is an asylum seeker - a figure that has now become a caricature, a stereotype in the way that 'Blacks', 'Jews' and 'Gypsies' have been and still are" (Schuster, 2003).

By employing the social constructionist perspective, this study will examine whether such a construction of asylum seekers prevails, or whether this reality has been altered. 
The second way that the theory of social constructionism is relevant to this study is in the sense that through its reporting on asylum seekers, the newsprint media works to construct the concept of the nation. By frequently contrasting the Canadian and American treatment of asylum seekers, the newsprint media constructs a Canadian national identity in opposition to America. The social constructionist view that reality is constructed through social interactions does not only apply to individuals and groups of people, but also to the ways in which we perceive abstract social concepts such as nation and state sovereignty. In the absence of humanity, these concepts would cease to exist, and as such their meanings are not based in a single reality but instead change depending on particular contexts. In this study, the social construction of asylum seekers was found to be influenced by the ways in which Canadians construct their identity in relation to Americans. While some legitimate differences do exist between the inhabitants of the two countries, most are socially constructed and work to further the concept of the nation as a distinct and unified entity. This study examines these cross-national constructions, and the ways in which the social construction of national identity in turn influences the social construction of asylum seekers, and of the effectiveness of Canada's government and immigration policy.

In addition to this large theoretical framework, the results of this study will be analyzed using the related concept of 'Othering', as presented by Edward Said (1978). Although the concept of the Other was first introduced by Georg Wilhelm Friedrich Hegel in the late eighteenth century in the context of self-awareness and introspection, it has been applied in several other fields. In Orientalism, Othering occurs when one group of people is mentally classified as being in opposition to oneself and one's own group, and against which one's own supposed superiority or normalcy is measured (Said, 1978). In particular, non-Western persons are presented as being in opposition to Westerners through three main processes: (i) 
homogenization, which suggests that all non-western are the same; (ii) feminization, where nonwesterners are viewed as 'less than' westerners; and (iii) essentialization, where non-westerners are presented as having universal, unchanging characteristics (Said, 1978).

Although it has distinct origins from social constructionism, the process of Othering is indeed a form of social construction in and of itself, whereby individuals and groups are constructed as being inherently different from others. In the context of this study, asylum seekers from the United States were often constructed as the Other, both in relation to Canadian citizens, and in relation to other more 'legitimate' types of refugees such as those which are resettled from abroad. Many of the analyzed articles also constructed the United States as the Other in relation to Canada and Canadians, and used these constructions as a form of Canadian national selfidentity formation.

\section{Literature Review}

This study's particular area of inquiry is new and emerging. An academic examination of Canadian newsprint media framings of the increase in asylum seekers crossing into Canada in the context of Donald Trump's election and the Canada-US Safe Third Country Agreement has not been undertaken until now. However it fits within and builds upon several widely-studied fields of inquiry. These include areas of study which focus on the Canada-US Safe Third Country Agreement, on Canadian national identity formation, and on the social construction of migrants. A review of the literature related to this study revealed three dominant themes: 1) Asylum seekers have generally been framed in a negative light by the Canadian media; 2) Literature examining various facets of the Canada-US Safe Third Country Agreement is harshly critical of it; 3) Canada's national identity formation largely occurs through its differentiation from the United States. This section will go on to address these three themes as they are found in 
the literature. It will demonstrate the ways in which the literature, in its current state, is inadequate in addressing the current research question, as well as the ways in which this research will contribute to existing areas of study.

\section{Theme 1: Negative Framing of Immigration in Canadian Newsprint Media}

The main theme to emerge from the review of the literature is the negative framing of immigration and migrants by the Canadian newsprint media (Bradimore \& Bauder, 2011; Greenberg \& Hier, 2001; Lawlor, 2015). A dominant study looking at the framing of immigration in Canada, and how it has changed over time, was conducted by Lawlor in 2015. Lawlor's study consists of a large-scale quantitative analysis of thousands of news sources in Canada and Britain, which were published between 1999 and 2013 (2015). To analyze such a large quantity of news sources, Lawlor employed automated content analysis (ACA). While the strength of this technique is that it allows for a cost-effective and time-effective way to analyze large quantities of text, it also has some pitfalls. For instance, complex sentence structures mean that the program's interpretation of certain words and phrases can differ drastically if new words are included in the analysis, or if others are excluded. As this current study is dealing with a much smaller quantity of text published over a much shorter period of time, a hand-coding approach has been taken which allows for complex sentence structures to be taken into account.

Despite this potential drawback of Lawlor's (2015) study, a large-scale analysis of the Canadian media's framing of immigration was necessary, and yielded some interesting results. She found that in Canada, the news media framed immigration in a rather inconsistent and eventdriven manner. This means that rather than finding consistent and gradually-evolving frames over the 15 year study period, Lawlor found that each time an immigration-related event took

place, the media altered its frame (2015). However, Lawlor's study concluded that overall, even 
in the absence of large immigration-related events that drew the media's attention, immigration and immigrants were presented within a negative frame by the news media (2015). While this study does not examine the media's representation of asylum seekers in particular, it is still relevant for the purposes of this study as asylum seekers are included within the broader realm of ‘immigration' which was studied.

Lawlor's conclusion, of a negative news media framing of immigration in Canada, is further confirmed by other related studies (Bradimore \& Bauder, 2011; Greenberg \& Hier, 2001). Bradimore and Bauder examined Canadian newsprint media reactions to the 2009 arrival of a boat of Tamil refugees off the coast of Victoria, British Columbia (2011). Their study analyzed articles which were published between October 2009 and January 2010 in the National Post, Toronto Star, and Vancouver Sun, and found that, “...there was an overall negative representation of the Tamil refugees as the press emphasized issues of criminality and terrorism, and constructed the refugees as risk" (2011 p. 638). Security, rather than human rights, was the way in which the Canadian newsprint media chose to frame the issue (Bradimore \& Bauder, 2011). As such, Bradimore and Bauder chose Beck's (1986) concept of risk, and the way it relates to a moral-panic approach, as their theoretical framework (2011). While this framework is interesting and relevant given the results of their study, it is not particularly relevant to this current study, as risk and security were not found to be the dominant ways in which asylum seekers are being framed by the Canadian newsprint media. The concept of risk and moral panic is relevant to the rhetoric emerging from the White House surrounding immigration-related issues, and is also employed by the Canadian newsprint media. However, as will be discussed below, the current dominant media framing of asylum seekers is in the manner of victims and human rights protections. 
A study conducted ten years earlier than Bradimore and Bauder's (2011), on a different immigration-related issue, yielded almost identical results (Greenberg \& Hier, 2001). In 1999, four unmarked ships carrying 599 undocumented Fujianese migrants arrived at Canada's west coast. Greenberg and Hier (2001), through their study of newsprint articles published on the topic between July 21 and October 1, 1999, found that the media framed this event as a "crisis" and that migrants were framed as dangerous and illegal (2001). Furthermore, they found that the state, and especially Canada's immigration system, were constructed as "failing" and in a state of crisis themselves (Greenberg \& Hier, 2001). Greenberg and Hier argue that the state and immigration system were indeed not failing, but that this perception was socially constructed through narrative (2001). As has been mentioned, social constructionism, as utilized by Greenberg and Hier is a useful theoretical framework for the purposes of this study. The analysis of two distinct Canadian national newspapers sheds light upon the ways in which the media socially constructs asylum seekers, and how those social constructions are also influenced by the ways in which Canada socially constructs its identity in relation to the United States.

Like the studies discussed in this section, this research builds upon Canadian communications research that examines media discourses in the context of immigration. However, given that this research examines related issues in an entirely different context irregular migration into Canada and the Canada-US Safe Third Country Agreement - the current results present a more positive construction of asylum seekers, associated with human rights rather than criminality.

Donald Trump has brought issues of immigration to the forefront of political debates and media discourses. However, given the very recent nature of these developments, there are very few academic studies which focus on Trump, and none which examine the ways in which 
Canada is being impacted by his policies and rhetoric. As such, this study seeks to fill this gap by examining dominant newsprint media framings of refugees and asylum seekers irregularly crossing into Canada in context of the Canada-US Safe Third Country Agreement.

\section{Theme 2: Academic Criticisms of the Canada-US Safe Third Country Agreement}

Academic studies which focus on the Canada-US Safe Third Country Agreement are overwhelmingly critical of the agreement, and particularly of Canada's participation in it (Arbel \& Brenner, 2013; Cutler, 2004; Harvard Law School, 2017; Sarbit, 2003; Vermont Law School, 2005). Sarbit (2003) examined discourses surrounding the Agreement before it even came into effect, and argued that, “...discourses of abuse by economic migrants and potential terrorists created an environment in which the Safe Third Country Agreement could be signed in spite of its detrimental effect on refugees" (p. 139). Furthermore, she claims that the Agreement is inconsistent with Canadian values and policy goals (Sarbit, 2003). Similarly, Cutler's (2004) study is highly critical of the Agreement, even going as far as comparing the detrimental effects of the Agreement on refugees to the way in which nations turned their backs on Jewish refugees during the Second World War. An examination of the Canada-US Safe Third Country Agreement by the Vermont Law School also criticizes the Agreement and its likely impacts, by painting a picture of desperate asylum seekers flocking towards Canada to escape the United States before the Agreement took place (Vermont Law School, 2005).

This current study reveals that dominant Canadian newsprint media discourses follow this trend of criticism of the Agreement, although for two main reasons, rather than a single one. First, criticism of the Agreement emerged in the sense that it creates unacceptable barriers for asylum seekers in need of protection. As it is argued that the United States is not a safe country

for asylum seekers, the Agreement is presented as hindering them from seeking safety in Canada, 
and as unnecessarily pushing them to face the dangers associated with crossing irregularly.

Claims that the US is not a safe country for refugees and asylum seekers are supported by recent reports which claim that Trump's Executive Orders could result in a lack of due process for asylum seekers, the large-scale detention of asylum seekers, and discrimination against asylum seekers based on factors such as nationality and religion (Amnesty International Canada \& Canadian Council for Refugees, 2017; Arbel \& Brenner, 2013; Harvard Law School, 2017). Criticism of the Agreement also emerged from those who believe that the Agreement should be strengthened in order to prevent asylum seekers who cross irregularly from being able to make an asylum claim once they cross into Canada.

In addition to being critical of the Canada-US Safe Third Country Agreement, most academic literature on the topic was published around the time of its creation and implementation, and generally takes a legal approach to its examination (Cutler, 2004; Macklin, 2005; Sarbit, 2003; Vermont Law School, 2005). Existing literature, most of which was published more than a decade ago, tends to examine the Agreement in a legal manner, holding it up to the standards of international law, including the Immigration and Refugee Protection Act (Sarbit, 2003; Vermont Law School, 2005). After 2005, interest in the Agreement seemed to die down, only recently being renewed following Donald Trump's election and the implementation of various policies which disadvantage non-citizens and encourage them to cross irregularly into Canada. The Executive Orders banning travel to the US for individuals of certain nationalities initially spurred the increase in irregular migration into Canada, but other immigration-related decisions made by Trump have also contributed to it. For instance, while many asylum seekers who crossed into Canada throughout the winter were nationals of countries affected by Trump's Executive Orders, a sizeable number of those who are crossing the border now are of Haitian 
origin (Stevenson, 2017). The reason for their arrival has to do with the fact that, “...the temporary protection status for Haitians in the US granted after the 2010 earthquake is set to expire in January" (Stevenson, 2017). The Trump Administration's decision not to renew the protection order has prompted Haitians who are fearing deportation from the US to seek protection in Canada (Stevenson, 2017). Such political developments which disadvantage noncitizens living in the US, coupled with widespread misinformation about Canadian immigration laws contribute to the increasing flow of irregular migration into Canada, and to the rise of interest in the Agreement.

However, thus far, recent interest in the Canada-US Safe Third Country Agreement has largely been from the media, with an absence of academic studies on the topic. This research study will fill these gaps in the literature by conducting an academic examination of the Agreement in terms of newsprint media discourses surrounding it, rather than through a legal analysis. It will also contribute to the literature examining the Agreement in a current and largely unexplored context.

\section{Theme 3: Canadian National Identity Formation}

The final theme which emerged during the review of the literature is that of Canada's national identity formation through self-differentiation from the United States in various media outlets (Melvin, 2005; Schwartz, 2010; Winter, 2007). Essentially, the review found that various Canadian media outlets, in their portrayal of America, influence the Canadian public's perception about both America and Americans. The public was found to utilize these media portrayals of 'America' in defining themselves as a nation. In the context of Canada's official policy of multiculturalism, 'America' serves as a useful construct of what Canadians are not (Melvin, 2005; Schwartz, 2010; Winter, 2007). Furthermore, the existence of America allows for 
the perpetuation of Canadian national myths, of being the comparatively gentler, kinder society than our neighbour to the South (Winter, 2007). This paper builds upon existing knowledge in this area, but in a new and emerging context which has not yet been studied. America in general, and the Trump administration in particular, were found to be largely framed by the Canadian newsprint media as the morally inferior Other, in the context of the Canada-US Safe Third Country Agreement and the recent increase in irregular border crossings into Canada. Such a representation in turn allows for the perpetuation of Canadian national myths, and for the construction of an identity in opposition to America and Americans.

The existing literature in this area of study, while insightful, tends to be rather broad and general. Winter (2007), examines the ways in which, “...images of 'America' play important roles for the multicultural reconstruction of Canadian nationhood" (p. 481). She claims that through the representation of America as an 'assimilating melting pot' within Canadian national discourses, America is constructed as what Canada is not (Winter, 2007). In conducting her study, she selected 350 articles from the Toronto Star and The Globe and Mail, which were published between 1992 and 2001. However, she does not make it clear how she chose the 350 articles, or how she ensured that they were relevant to her study. Furthermore, the fact that Winter's (2007) study only analyzed articles from the Toronto Star and The Globe and Mail may be problematic. The Toronto Star is a left-leaning periodical, and The Globe and Mail is considered to be centre-left. This leaves the more right-leaning national perspectives unrepresented in Winter's (2007) study. This study ensures a more balanced representation of newspapers' political orientations by examining articles published in The Globe and Mail, a centrist/economic liberalist publication, and in the National Post, a conservative publication. 
Similarly, Schwartz (2010), employs a very general approach in her examination of the ways in which the American government was presented in CBC-TV national news broadcasts during the 1960s. Finding an answer to the research question, "How was the United States presented on newscasts prepared by the CBC-TV National News Service in the 1960s?" is very difficult, given the broad magnitude of topics about America which were likely reported on. For instance, America could be presented in a positive light in terms of art and cultural developments, but in a negative light in terms of its political operations at the time. As such, Schwartz would have benefitted from asking a narrower question. To avoid the difficulties which arise from asking too broad of a question, this study follows the approach taken by Melvin (2005), and examines Canadian media reactions to a particular immigration-related issue, rather than to the Trump administration or the framing of asylum seekers as a whole.

While the literature which examines the ways in which Canadians construct an identity in relation to America finds that Canadians tend to differentiate themselves from Americans, it also finds that this process of differentiation takes form largely without criticism and hostility towards the United Sates (Melvin, 2005; Schwartz, 2010; Winter, 2007). Through her examination of the CBC-TV National News Service in the 1960s, Schwartz found that at the time, Canadian media constructs of America were moderately favourable (2010). This trend seemed to prevail into the $21^{\text {st }}$ century, as Winter's (2007) study of Canadian newsprint media found that constructions of America are characterized by a mix of envy and admiration. This moderate and implicit approval of America in the Canadian media was found to transform into explicit and unwavering support in a time of crisis, as exemplified by Melvin's (2005) study in the context of 9/11. This current study builds upon the body of literature dealing with Canadian media representations of America, as recent increases in irregular migration into Canada in the 
context of the Canada-US Safe Third Country Agreement stem directly from political developments in the United States. However, given the unprecedented nature of an administration such as Trump's in the White House, and given the seemingly opposing stances on immigration-related issues taken by Trudeau and Trump, this study demonstrates a break from the trend of positive representations of America by the Canadian news media. Current negative media representations of America are corresponding with negative public perceptions of America among Canadians (Dale, 2017), and are largely a result of the Trump administration's stance on immigration-related issues. The issue of asylum seekers and their inadequate treatment under Trump is thus providing Canadians with a means of self-differentiation from the United States, by portraying themselves as a country invested in the fair and generous treatment of asylum seekers.

This literature review has demonstrated that while this study topic is new and emerging, and has not yet been addressed, it fits within and will build upon several widely-studied fields of inquiry. These include areas of study which focus on critiques of the Canada-US Safe Third Country Agreement, Canadian news coverage of American events, Canadian national identity formation, and the social construction of migrants. This paper builds upon these bodies of literature in a unique and relevant context which has yet to receive much academic attention.

\section{Methodology}

\section{Researcher Location}

Researcher reflexivity has been found to be affected by whether the researcher shares the experiences of the researched (and thus has an insider perspective on the issue at hand), or whether he or she does not (and thus holds an outsider perspective) (Berger R. , 2013). As such, 
prior to beginning this study, it was important that I recognized that I was refugee myself and that this life experience will likely influence the way in which I analyze issues related to refugees entering Canada in the context of the Canada-US Safe Third Country Agreement. Given that admittance into Canada provided me and my family the opportunity to escape a war-torn country and restart our lives in a safe and secure environment, I am likely more empathetic to the plight of refugees crossing irregularly into Canada than many other people might be. In some sense, although my experience is not identical to the one that I am studying, I hold an insider perspective. As such, I must acknowledge my positionality, and periodically remind myself to give equal weight to all framings of migrants which I come across in my analysis, rather than focusing more on those which reflect my personal experiences and dismissing those which do not.

Something else which influences my position as a researcher is the fact that I have more experience and am more comfortable with qualitative research approaches than quantitative ones. Ultimately, my lack of experience with quantitative research approaches and statistical analyses of information is what led me to choose a qualitative approach for my proposed research study. While I do believe that a qualitative approach is appropriate for this study and has yielded interesting results, had I had more experience with quantitative research approaches, I may have also considered a mixed-methods approach for this study.

\section{Research Approach}

This research study is qualitative in its approach for several reasons, the main reason being that it is an inductive and exploratory study on a topic which is largely unaddressed. Rather than looking to test a pre-determined hypothesis or to uncover statistical relationships between variables, this study is looking to take a less structured approach and uncover embedded 
themes and rhetoric which are being used in the Canadian newsprint media to frame the current increase in asylum seekers from the United States in a certain way. New concepts, and connections between these concepts, continued to emerge throughout the entire duration of the data collection process, and a qualitative approach allowed me to adequately address them. Furthermore, the study's relatively small sample size (83 newsprint articles in total, the majority of which are rather short) made it possible to conduct an in-depth rigorous examination of the articles, rather than, for example, looking for broad patterns in thousands of articles published over several years, as some quantitative studies have done (Lawlor, 2015). Therefore, a qualitative approach allows for the development of a narrow and nuanced understanding of a relatively small sample.

While this study is qualitative and does not entail any form of statistical analysis or mathematical manipulation of variables, it does at times employ the counting of concepts and codes which emerged during data analysis. Counting the frequency of particular codes, and counting the articles which tend to frame the situation in a certain way, allows for comparisons to be made and conclusions to be drawn. It also allows for the use of semi-quantification (e.g. the use of terms such as many, most, few, etc.) when presenting the results of the study. While there has been some controversy regarding the role of counting in qualitative research and whether it should be done at all, it appears that the consensus is that counting can be beneficial in qualitative research to the degree which, “... readers of the article believe that the numbers produced constitute, in and of themselves, valid and convincing evidence of the claims being made by the authors" (Hannah \& Lautsch, 2011 p. 16). 


\section{Research Strategy}

The research strategy employed for the purposes of this study is that of 'directed qualitative content analysis.' The reasons for choosing content analysis as a research strategy are rather clear, as this study does not involve human subjects in any way, but rather existing text, from which meaning is to be interpreted. Discourse analysis was also considered as a research strategy, but seemed to be more appropriate for analyzing naturally occurring text, such as interview transcripts, rather than for newspaper articles (Willig, 2013).

This research strategy was then further narrowed down. A 'directed' approach to qualitative content analysis entails beginning the coding process with predetermined codes (Hsieh \& Shannon, 2005). Such an approach is taken when there is already existing research on a topic, and when that research is then used to inform the study at hand. In this case, while there is no existing research on the framing of asylum seekers in the Canadian newsprint media in the particular context which this study examines, there is research which examines the framing of migrants in various different contexts. Much of this research finds that migrants, and in particular asylum seekers, are framed as a risk/security threat (Bradimore \& Bauder, 2011; Fryberg et al., 2011; Greenberg \& Hier, 2001), victims in need of compassion and human rights protection (Canadian Council for Refugees, 2017), or as ‘bogus' claimants taking advantage of a country's refugee policy (Macklin, 2005; Sarbit, 2003). As such, the directed qualitative content analysis employed in this study began with these three broad categories in mind. As the data collection process continued, however, these codes and categories were modified, and new ones were added (Hsieh \& Shannon, 2005). 


\section{Data Collection}

For the purposes of this study, data was collected from two different periodicals: The Globe and Mail, and the National Post. The Globe and Mail and the National Post were chosen to be examined because they are Canada's two national newspapers, and this study aimed to examine the framing of asylum seekers in the newsprint media as a national issue, rather than as a municipal or local issue of the border towns and communities into which asylum seekers are directly crossing. While an analysis of local newsprint media would provide an interesting glimpse into the reality of what irregular migration means for those living in Canada's border communities, an understanding of national media discourses yields a greater amount of insight into potential legal and policy changes which may take place at the federal level. National newsprint media discourses often reflect dominant Canadian public perceptions on issues such as immigration, and these public perceptions can influence the actions of elected officials. As such, it is these dominant public perceptions that this paper aims to provide insight into. In addition to this, The Globe and Mail and the National Post were chosen for examination because they have high readership rates and represent differing political stances. The Globe and Mail is considered to be a centrist/economic liberalist publication, whereas the National Post is considered to be more conservative. It is important to note that this study does not aim to provide a comparative analysis of the articles published in these two periodicals. Instead, it examines all of the articles as one body of data, as they all come together to form the national newsprint media framings of asylum seekers.

In order to locate relevant articles for analysis within these two periodicals, this study employed a keyword search on each newspapers' website. With the digital archiving of print articles, keyword searches have emerged as a time-efficient and relatively accurate method for 
gathering relevant data. However, since print products have limited space it is possible that print and online versions of a publication are not identical. Online versions of newspapers, unaffected by spatial restrictions, tend to contain a broader selection of articles. As such, the online versions of these periodicals were searched for relevant articles. This allowed for an increase in trustworthiness of my data collection tools and process, as all relevant articles containing the selected keywords were able to be considered, and none were left out.

Relevant articles published between the dates of January 27, 2017, and April 27, 2017 were considered in this study. January 27, 2017 was specifically chosen in order to ensure the relevance of the articles considered in my study. On this date, Donald Trump signed the Executive Order Protecting the Nation from Foreign Terrorist Entry into the United States and as such, sparked media interest in the Canada-US Safe Third Country Agreement. Articles brought back by the keyword search prior to this date are few, and are irrelevant to my study as they examine the Agreement in an entirely different context, i.e. in the legal context when the Agreement was first implemented. April 27, 2017 was specifically chosen as the end date for this study's sample collection because it marks exactly three months since the data collection start date. Furthermore, while the months of February and March yielded a significant number of relevant articles, this number significantly decreased in April, and by the end of April relevant published articles in both considered periodicals were few and sparse.

Initially, the phrase "safe third country agreement" was used for the keyword search. It yielded 43 relevant articles in The Globe and Mail, and 14 relevant articles in the National Post. As a measure to increase this study's trustworthiness, and ensure that no relevant articles were left unconsidered, three additional terms were added to the keyword search. The terms "irregular", "border", and "asylum" were searched, and yielded an additional 16 relevant articles 
in The Globe and Mail, and an additional 10 relevant articles in the National Post. Therefore, a total sample of 83 articles was considered in this study. This sample includes both 'opinioneditorial' and 'hard news' pieces. The decision to include both types of articles was made because they are both being published by Canada's two national newspapers and are both being consumed by readers. Therefore, both types of articles contribute to the construction of asylum seekers in the minds of the Canadian people.

\section{Results}

In this section, the results of the directed content analysis will be presented in an objective manner, absent of any practical or theoretical explanation or interpretation, as that will be done in the following section. This research study asked the question, "How is the Canadian newsprint media framing the asylum-seekers crossing into Canada from the United States?" Seven distinct framings of asylum seekers were identified, each of which will be addressed.

As this study employed the research strategy of "directed content analysis", it began with a set of pre-determined codes which were based off of the findings of past related studies. As mentioned in the Methodology section, much of the existing research finds that migrants, and in particular asylum seekers, are framed as either a risk/security threat (Bradimore \& Bauder, 2011;

Greenberg \& Hier, 2001), victims in need of compassion and human rights protection (Canadian Council for Refugees, 2017), or as 'bogus' claimants taking advantage of a country's refugee policy (Macklin, 2005; Sarbit, 2003). This study was found to be consistent with such past research, as all three framings emerged in the analysis. Four additional framings also emerged, however: refugees as 'agency/rights-bearing', refugees as 'burdens', refugees as 'culturally incompatible' with Canadian society, and refugees as 'beneficial to Canadian society'. Most of the 83 analyzed articles employed more than one framing of asylum seekers. For instance, an 
article could be sympathetic to the plight of asylum seekers and frame them as victims of war, while at the same framing them as burdens to Canadian taxpayers. Table 1 (below) lists the seven identified framings of asylum seekers in the Canadian newsprint media and their orientations, and specifies the number of articles in which each of them was employed.

Table 1: Frequency of Framings

\begin{tabular}{|c|c|c|}
\hline Framing of Asylum Seekers & Orientation of Framing & Number of Articles \\
\hline Victim/Human Rights & Positive & 49 \\
\hline Risk/Security & Negative & 32 \\
\hline Rational/Rights-bearing & Positive & 30 \\
\hline Bogus/Illegitimate & Negative & 21 \\
\hline Burden & Negative & 14 \\
\hline Culturally Incompatible & Negative & 5 \\
\hline Beneficial to Canada & & 4 \\
\hline
\end{tabular}

As shown in the table above, the 'victim/human rights' framing of asylum seekers is employed in the greatest number of articles, 49 out of 83 . The rest of the framings were employed as follows: the 'risk/security' framing was employed in 32 articles, the 'agency/rightsbearing' framing was employed in 30 articles, the 'bogus/illegitimate' framing was employed in 21 articles, the 'burden' framing was employed in 14 articles, the 'culturally incompatible' framing was employed in five articles, and the 'beneficial to Canada' framing was employed in four articles. Each of these framings will now be further discussed. 


\section{'Victim/Human Rights'}

The 'victim/human rights' framing is employed in a larger number of articles than any of the other framings of asylum seekers which arose throughout the analysis. Essentially, any instances in which asylum seekers were presented as being legitimate victims in need of support, and in which sympathy-evoking language or humanizing details were utilized, are considered to fall within this framing.

Articles which employed this framing of asylum seekers largely used legitimizing terminology which was absent of the concept of illegality when referring to them. In particular, the terms 'asylum seekers' and 'refugee claimants' were utilized. When referring to the crossings which these individuals made, the terminology used was also generally absent of the concept of illegality. The articles which employed an entirely 'victim/human rights' framing of asylum seekers utilized phrases such as 'irregular crossings', 'unofficial crossings', and crossings made 'outside of regular ports of entry'. However, those which employed a 'victim/human rights' framing along with one or several additional framings tended to refer to the crossings using phrases such as 'refugee claimants who illegally crossed' and 'people crossing the border illegally'. Such terms acknowledge that the asylum seekers' method of entry into Canada is against the law, without being critical of the individuals themselves.

Articles employing the 'victim/human rights' framing also tended to frequently give voice to both rights groups which advocate for asylum seekers and refugees, and to asylum seekers themselves. 'Voice', or a platform to directly speak, was given to refugee rights groups and individuals in 21 articles. These actors include protesters from groups such as No One Is Illegal, refugee lawyers across Canada, and even seemingly unrelated actors such as the Canadian Pediatric Society, who voiced their support for the rights of asylum seekers crossing 
into Canada from the United States. Asylum seekers themselves were also given voice. 15 articles included direct quotations from individuals who had made the journey to Canada on foot from the United States. They addressed the topics of feeling unsafe in the United States due to the Trump administration and a general xenophobic environment; of the long, dangerous, and cold journeys they had taken to get to Canada; and of the persecution they would face if deported to their countries of origin.

As stated, under this framing the legitimacy of asylum seekers is unquestioned, as they are framed as legitimate victims who are in need of support. Articles employing this framing accept that these individuals would face persecution if they were to be deported, and do not question whether their asylum claims will eventually be accepted. In addition to the asylum seekers themselves being presented as legitimate victims, their way of entering Canada is presented as being legitimate as well. The asylum seekers are portrayed as being equal to all other refugees and asylum seekers in the country, regardless of their method of entry into Canada. Furthermore, the act of irregularly crossing the border into Canada from the United States is presented not as a choice and more as an act of desperation by individuals who are seeking safety for themselves and their families. While the irregular crossings which these individuals undertake are in some cases presented negatively due to being one of the many risks these asylum seekers have had to take in their lives, the criticism is directed at the laws which push them to do so rather than to the individuals themselves.

In order to present these asylum seekers as legitimate victims in need of protection, articles employing this framing rely on frequent use of sympathy-evoking language. Most frequently, sympathy for asylum seekers was evoked through detailed descriptions of their journeys to Canada. These descriptions spoke of asylum seekers' long treks through waist-deep 
snow and freezing temperatures, and emphasized the danger of the journey by referring to the instances in which asylum seekers lost fingers and toes to frostbite, and describing their often inadequate winter clothing. The descriptions also evoked sympathy by emphasizing instances in which children were involved in the crossings, and that the families were travelling with the entirety of their personal possessions.

Sympathy for the asylum seekers who are crossing into Canada from the United States was further evoked through the regular use of humanizing details of individual asylum seekers. Individual names (or aliases if they wished not to be identified) were provided, along with their countries of origin and the particular circumstances which led them to seek asylum in Canada. Their appearances were described, and their emotions of fear, uncertainty, and anxiety were regularly relayed in the articles. Individual background stories, of living in refugee camps and of being forced to flee from the specific villages and towns in they previously lived, were regularly described as well. Some articles within this framing also sought out asylum seekers which had crossed into Canada in prior months, to follow up with them and share details about what had taken place in their lives since arriving in Canada.

\section{'Risk/Security'}

The 'risk/security' framing is the second most frequent way in which asylum seekers were framed, with it being employed in 32 out of the 83 analyzed articles. Essentially, any instances in which asylum seekers were presented as being a risk to the security of the Canadian people or to the functioning of various aspects of Canada as a nation are included within this framing. 
The terminology used in articles which employed the 'risk/security' framing to refer to both asylum seekers and their crossings was significantly less legitimizing than the terminology which was often utilized in articles employing the 'victim/human rights' framing, and it tended to evoke the concepts of illegality and criminality. The terms 'border jumpers' and 'border crossers' were frequently used to refer to the asylum seekers, as were 'migrants' and 'illegal immigrants'. In terms of the border crossings which these individuals were undertaking, the term 'illegal crossings' was most frequently used. While their border crossings are indeed against Canadian law, and the term itself is not delegitimizing, it is significant to note that within this framing, the term 'illegal crossings' was used much more frequently than in the 'victim/human rights' framing. This framing also tended to utilize phrases such as 'sneaking across the border', by which the asylum seekers were presented as trying to avoid detection by border patrol officers and police.

Asylum seekers crossing irregularly into Canada from the United States were presented as posing a risk to the security of the border, and to the integrity of the Canadian immigration system. Articles which employed the 'risk/security' framing of asylum seekers tended to view immigration as a national security issue, and thus expressed concern about the fact that increasing numbers of asylum seekers made the border less secure and weakened the control that Canada as a nation had over who came into the country. The fact that asylum seekers were presented as being a risk to the integrity of the Canadian immigration system has to do with the assumption that Canadians have historically had a high level of trust in the effectiveness of the system, and that the increasing number of asylum seekers from the United States would diminish that trust. 
While the majority of articles which employed the 'risk/security' framing of asylum seekers did so in the context which was discussed in the preceding paragraph, there were some articles within this framing which also presented the asylum seekers as posing risks to Canadians. Several articles raised concerns about the fact that asylum seekers were not detained until their asylum claim could be heard but were instead permitted into the public sphere, and therefore negatively impacted Canada's safety. In other articles, the concern was that Canadians do not know who the people that are crossing the border are. Concern was also expressed about the increased risk that irregular border crossings posed to border patrol officers, and to the people living in the border communities into which the asylum seekers were directly crossing particularly Emerson, Manitoba. These security concerns were most often followed by claims that irregular crossings not only make Canadians unsafe, but asylum seekers as well. Two main solutions emerged from such claims. The first was that border security needed to be enhanced in order to increase Canadians' and asylum seekers' mutual safety. The second was to increase and improve legal channels for entering the country, as a means of increasing mutual safety. This second proposal suggests that part of the reason why asylum seekers are framed negatively by the newsprint media has to do with the risks associated with their method of entry into Canada, rather than the fact that they as individuals are inherently risky.

Articles which employed the 'risk/security' framing of asylum seekers also presented them as posing a risk to Canada due the large numbers in which they are arriving, and due to the likelihood that those numbers would further increase. Many articles alluded to the refugee situation currently taking place in Europe and claimed that a similar situation was possible in Canada as well. Terminology such as 'surge', 'influx' and 'flood' was used to refer to the asylum seekers currently crossing into Canada. Concerns were further elevated in regards to the 
increases which may take place in the future, once the weather begins to warm, and were referred to by terminology such as 'crisis' and 'chaos'.

\section{'Agency/Rights-bearing'}

The third most frequent framing of asylum seekers revealed throughout the analysis was the 'agency/rights-bearing' framing, which was employed in 30 articles. Falling within this framing are any instances in which the rights that individuals crossing into Canada from the United States hold as asylum seekers are affirmed. Also included are the instances in which asylum seekers are presented as having agency in the choices which they make and in the things that happen to them. While this framing of asylum seekers was employed in 30 out of the 83 analyzed articles, it was rarely employed as an article's dominant framing. Instead, it was typically only briefly employed within articles which also employed the 'victim/human rights' framing.

As the two major positive framings of asylum seekers revealed in this study, the 'victim/human rights' framing and the 'agency/rights-bearing' framing employed similar terminology when referring the individuals who were crossing and to the crossings which they were making. The terminology that was used within this framing to refer to asylum seekers legitimized their realities as individuals who are fleeing persecution. In particular, the terms 'asylum seekers' and 'refugee claimants' were utilized. These terms are in opposition to terms such as 'migrants' and 'illegal immigrants' which question their status and motives for coming to Canada. When referring to the border crossings which the asylum seekers made, the terminology utilized was generally absent of the concept of illegality. Phrases such as 'irregular crossings', 'unofficial crossings', and crossings made 'outside of regular ports of entry' were common. 
Many of the instances in which the rights of asylum seekers were affirmed took place through voice being given to organizations and individuals who advocate for the rights of refugees and asylum seekers. Individual refugee lawyers, as well as groups such as No One is Illegal, Amnesty International, and the Canadian Association of Refugee Lawyers utilized both Canadian national laws and international laws and obligations to present the asylum seekers crossing into Canada from the United States as possessing rights. The Canadian Constitution and the 1951 UN Convention Relating to the Status of Refugees were among the most frequently cited. In particular, it was emphasized that once they were physically on Canadian soil, these individuals possessed certain rights based on that fact alone, and that they are to be viewed and treated in the same manner as any other asylum seekers in the country, regardless of their method of entry.

Within this framing, asylum seekers were also presented as possessing agency over the events which take place in their lives. The most frequent context in which their agency was demonstrated was through the representation of irregular border crossing as a rational and purposeful choice, given the political situation in the United States and the existence of the Canada-US Safe Third Country Agreement. Asylum seekers were presented as individuals who had the knowledge and the means to effectively alter the course of their lives, regardless of the many obstacles (i.e. the Agreement, and Canada-US border laws) which stood in their way.

\section{'Bogus/Illegitimate'}

The 'bogus/illegitimate' framing of asylum seekers was employed in 21 out of the 83 analyzed articles, and it was employed in three ways: 1) asylum seekers crossing into Canada from the United States were presented as 'jumping the queue' to get into the country, 2) their legitimacy as asylum seekers was questioned, and 3) they were presented as abusing Canadian 
laws for their own purposes. Articles employing this negative framing tended to use much of the same terminology as those which employed the 'risk/security' framing. Delegitimizing terminology such as 'illegal immigrants' and 'border jumpers/crossers' was used to refer to asylum seekers, and phrases such as 'illegal crossings' and 'sneaking across the border' were utilized to refer to their method of entry into Canada.

Within this framing, asylum seekers were presented as jumping the queue to get into Canada because they decided to enter the country without authorization or proper documentation, as opposed to, for instance resettled refugees. As such, they were presented as being less legitimate than this other stream of refugees. The concept of 'unfairness', both towards refugees waiting to be selected for resettlement, and towards the Canadian immigration system was raised within this framing, as was the contrast between what are considered to be 'proper' and 'improper' methods of entry into the country.

The second way in which the asylum seekers crossing into Canada from the United States were presented within the 'bogus/illegitimate' framing was through the questioning of their legitimacy as asylum seekers. Several articles suggested that rather than being legitimate victims who are fleeing persecution and are in need of protection, the asylum seekers were actually economic migrants looking to come to Canada for the purposes of financial gain. Articles which presented the asylum seekers in this manner suggested that many asylum claims from these individuals would be denied, and as such called for the speeding up of the refugee determination process, so that non-refugees could be deported quickly.

Finally, articles which employed the 'bogus/illegitimate' framing of asylum seekers also presented them as abusing Canadian laws and taking advantage of 'Canadian generosity'. Several articles suggested that the asylum seekers viewed Canada as an 'easy target' and 
believed that crossing the border irregularly was a 'free ticket' into the country. Furthermore, many articles accused the asylum seekers of 'asylum shopping', and of originally obtaining American visas for the purpose of eventually making their way north into Canada.

\section{'Burden'}

Asylum seekers crossing into Canada from the United States were also framed as a 'burden' in some instances. Out of the 83 newsprint articles which were analyzed, 14 employed this framing. Essentially, any instances in which the asylum seekers were presented as inconveniencing or burdening particular Canadian actors or Canada as a nation were included within this framing, whether due to their resource and settlement needs, or due to their disruption of life in Canadian border communities. Concerns over the need for various resources to accommodate the asylum seekers were presented within this framing, as were the inconveniences which the asylum seekers were seen as posing to ordinary Canadians. The terminology used within this framing to refer to asylum seekers tended to legitimize them as individuals who are seeking asylum. At the same time, however, the terminology acknowledge that their method of entry was the problem. Phrases such as 'refugee claimants who had illegally crossed' and 'people who crossed the border illegally' were common.

The main way in which the asylum seekers were presented as being a burden to Canada, was through the cost and resource pressures that their arrival was placing on various municipal and provincial services. Provincial and municipal law enforcement and emergency response services were presented as being particularly overwhelmed by the asylum seekers, who were presented as diverting their attention from servicing existing Canadian communities. The cost associated with various settlement challenges, such as finding suitable temporary housing and legal representation for the asylum seekers, was also presented as a burden on Canadians. Within 
the context of 'asylum seekers as a burden', however, not all criticism was directed towards the asylum seekers themselves. Articles which employed the 'burden' framing along with the 'victim/human rights' framing were also very critical of the federal government for not contributing enough financially, and for not 'burden-sharing' with the provincial and municipal governments.

In addition to being framed as presenting a burden to the three levels of government and various aid/settlement organizations, asylum seekers were also presented as being a burden to ordinary Canadians as well. The various resources which they required were framed as being a drain on taxpayer dollars, which in their absence could have been used towards the benefit of Canadian citizens. Furthermore, the asylum seekers were presented as inconveniencing those Canadians who lived in the municipalities right along the border, into which they were directly crossing. Instances in which the asylum seekers sought help from Canadians, sometimes in the middle of the night, were mentioned in articles which employed this framing, as were instances in which local facilities were required to be made available to shelter the asylum seekers.

\section{'Culturally Incompatible’}

The framing of asylum seekers as 'culturally incompatible' was notable not because it emerged frequently throughout the analysis, but because it did not. Only five out of the 83 analyzed articles employed this framing of the asylum seekers crossing into Canada from the United States. The five articles did not show a clear trend in the terminology used, often referring to asylum seekers both as 'refugees' and 'migrants' within the same article. The border crossings, however, were referred to through the lens of illegality, which is consistent with the ways in which the other negative framings of asylum seekers referred to them. 
The articles which employed the 'culturally incompatible' framing of asylum seekers tended to claim that asylum seekers would have trouble integrating into Canada because of the differences that exist between Canadian culture and the cultures of their countries of origin. While some articles expressed concerns about their adaptability due to factors such as language incompatibility and 'incompatible values', others suggested that the asylum seekers were capable of integrating into Canadian society but simply unwilling to do so. This negative framing of asylum seekers tended to emerge in articles which consulted Conservative members of parliament about their views on the issue of irregular border crossings. The Conservative voices which emerged in these articles demonstrate the ways in which political discourses influence media discourses, and how both jointly contribute to the social construction of asylum seekers in Canada.

\section{'Beneficial to Canada'}

The least frequent framing which emerged throughout the analysis was the framing of asylum seekers as 'beneficial to Canada'. Any instances in which asylum seekers were presented as benefitting any aspect of Canadian society or life in Canada were included within this framing. As only four out of the 83 analyzed articles employed this framing of asylum seekers, a clear trend in the terminology utilized to refer to asylum seekers could not be identified, although the tone tended to be positive and legitimizing.

Within this framing, the asylum seekers themselves were presented positively in the sense that they were hardworking, wanting to seek employment in Canada, and ready to contribute to their new societies. The many legal and procedural restrictions in place which make such participation and contribution difficult were criticized. The increased numbers in which the asylum seekers were arriving were also presented as having the potential to benefit Canada, by 
addressing the low population rates in various parts of Atlantic Canada, and by possibly resulting in a 'brain gain' for Canada.

\section{Discussion of Results}

All aspects of our social lives are socially constructed, and the ways in which they are constructed are largely dependent upon individual lived experiences and realities. The seven identified framings of the asylum seekers which were discussed above are a strong example of the prevalence of social constructionism within the Canadian newsprint media. Social constructionism holds that rather than having an objective and unchanging meaning, individuals and groups construct reality in a certain way, through social interactions (Berger \& Luckmann, 1966). A vast amount of individual social interactions and interpretations of those interactions came together to influence the social constructions of asylum seekers identified in this study. Each framing identified in the previous section represents an entirely different social construction by the newsprint media, and thus an entirely different understanding, of the same 'reality' - the increase in asylum seekers irregularly crossing into Canada from the United States in the context of Donald Trump's policies and the Canada-US Safe Third Country Agreement. These media framings and the social construction of asylum seekers within them are the result of an immeasurable number of factors, such as both the journalists' and public's political views, moral standards, social locations, knowledge and understanding of Canadian immigration laws, and biases towards newcomers to Canada, among many others.

The results of this study present a shift in the construction of asylum seekers by the Canadian newsprint media, away from the common negative portrayal (Bradimore \& Bauder, 2011; Fryberg, et al., 2011; Greenberg \& Hier, 2001; Lawlor, 2015), and more towards a positive portrayal. This shift is rooted in an apparent recognition by the newsprint media that the asylum 
seekers crossing into Canada from the US are genuinely victims in need of the protection which they seek, but are also rational individuals who possess agency and have rights, and whose presence has the potential to benefit Canada as a nation. Social constructionism holds that social interactions, particularly language and speech, alter our social realities and the meanings which we assign to various people and concepts (Galbin, 2014). The negative rhetoric about asylum seekers currently permeating from the US coincides with a positive shift in the representation of asylum seekers in the Canadian newsprint media. As such, the Canadian newsprint media appears to be responding to this negative rhetoric in a way which distances Canada from it, and alters the social construction of asylum seekers to reflect the core values of the Canadian national identity - kindness, acceptance, and generosity.

The terminology used to refer to the asylum seekers and to the border crossings they were making played an integral role in the ways in which they were framed. Generally, articles which constructed asylum seekers in a positive manner employed terminology which reinforces these individuals' legitimacy as asylum seekers, and which is absent of the concepts of illegality and criminality. For the individuals crossing into Canada, the terms 'asylum seekers' and 'refugee claimants' were utilized, both which imply an unquestioned acceptance of the fact that they are legitimately coming for the purposes of claiming asylum and seeking refugee status. These terms are in contrast to delegitimizing and even criminalizing terminology evoked in the articles which portrayed asylum seekers negatively, such as "migrants", "illegal immigrants", and "border jumpers". Such terminology calls into question the motives of the asylum seekers, and does not automatically accept that they are coming to Canada to claim asylum.

This shift in the construction of asylum seekers also took place largely through the newsprint media's use of sympathy-evoking language and humanizing details when referring to 
them. Like the terminology which was utilized, such rhetoric worked to construct them as being legitimate victims who are in need of support. Although such a representation does not portray asylum seekers in a strong and empowering way, it is positive because it legitimizes their experiences as asylum seekers, and because it demonstrates that there is a genuine need for support to be provided to them. In particular detailed accounts of asylum seekers' long and often dangerous journeys to Canada were provided. Descriptions of long treks through waist-deep snow and freezing temperatures, of asylum seekers losing fingers and toes to frostbite, and of women and children travelling on foot with the entirety of their personal belongings strapped to their backs all worked to evoke sympathy from the public and construct the asylum seekers as being legitimate victims who are in need of support from Canada and Canadians. Humanizing details which described individual asylum seekers were also provided for the same purpose. The appearances and journeys of individual asylum seekers were thoroughly discussed, and worked to construct an identity for the asylum seekers, and to allow Canadian citizens to view them as potential members of their communities, rather than simply as faceless, nameless Others.

Although the framing of asylum seekers as desperate victims was common in the articles which were analyzed, there were also many instances in which asylum seekers were portrayed in an empowered manner. They were presented as having agency over their lives and over the choices which they made, rather than as simply being pushed along through life by forces which were beyond their control. They were also portrayed as possessing certain rights by virtue of being asylum seekers, and as individuals whose presence in Canada could benefit the country as a whole. Such positive and empowering portrayals of asylum seekers are largely absent from past academic literature which examines the Canadian newsprint media. The frequency with which it emerged in this study suggests that it reflects the growing positive representation of 
asylum seekers in Canada, spurred both by the pro-immigration rhetoric emerging from Canada's Liberal government, and from the media's attempts at reinforcing Canadian national myths of kindness and generosity, in differentiation from the US under Trump.

The most frequent way in which asylum seekers' agency was demonstrated was through the construction of irregular border crossings as a rational and purposeful choice. Rather than portraying them as a criminal act, or as a thoughtless act of desperation, many articles constructed the border crossings as rational choices, made by individuals who were seeking safety and aiming to improve their situations. While the asylum seekers were generally not criticized for crossing into Canada irregularly - and were even in some cases praised - there was a high level of criticism of the factors which are seen as contributing to the need for individuals to cross irregularly in the first place - the insecure political climate in the United States, and the Canada-US Safe Third Country Agreement.

Furthermore, some of these articles presented the asylum seekers' decisions to come to Canada as a positive choice, benefitting both themselves and the wider Canadian community. They were portrayed as hardworking individuals who are ready and willing to seek employment and contribute to their new societies. Within this context, these articles were also very critical of the various legal and procedural restrictions and barriers which make seeking employment while awaiting an asylum claim decision rather difficult. Asylum seekers were also presented as benefitting Canada in the sense that an increasing number of irregular arrivals could be beneficial for addressing low population rates in many parts of Canada, and the idea that the increasing arrivals could contribute to a 'brain gain' for Canada. Within this positive framing, asylum seekers are constructed as positive and active participants in Canadian society, and as belonging to the community rather than being outside of it. 
A significant aspect of articles which framed asylum seekers in a positive manner, is that 'voice' was frequently given to refugee rights groups and to asylum seekers themselves. Giving voice, or providing a platform on which one can speak for themselves rather than being spoken on behalf of, is an important component of balancing unequal power relations between often marginalized individuals and groups who are being studied or written about, and those who are studying and writing about them. It allows individuals to tell their own stories absent of outside interpretation and analysis. This study found that when given voice by the newsprint media, many asylum spoke of first feeling unsafe in their countries of origin, and then again feeling unsafe in the United States given the current political climate, thus making the decision to head north and claim asylum. They believed that the combination of Donald Trump's presidency, and the general climate of xenophobia in the United States would hinder a fair decision from being made regarding their application for asylum in the United States.

However, it is not always possible for the individuals who are being studied or reported on to speak for themselves. Reporters' access to asylum seekers is very limited, unless they are located in the few parts of the country which are experiencing the bulk of irregular border crossings. Even then, it is likely that many asylum seekers who reporters may encounter are unable or unwilling to speak for themselves. Language barriers between asylum seekers and reporters serve as impediments for the giving of voice, but an even greater issue is the fact that asylum seekers may be reluctant to speak to reporters for fear of repercussions, both in Canada during the refugee determination process, and to their families in their countries of origin. When this is the case, the next best thing that reporters who wish to give voice to asylum seekers can do is provide a platform to speak for those organizations and individuals who are committed to helping them. These actors echoed asylum seekers' concerns about their feelings of unsafety in 
the United States, and hopes for finding safety, compassion, and fairness in Canada. Such representation of asylum seekers, as fearing for their safety both in their countries of origin and in the United States, worked to successfully construct them as desperate victims in need of support.

The inclusion of rights-groups' and other actors' voices in the newsprint media also worked to construct asylum seekers as individuals who have rights, rather than individuals who are infringing upon other people's rights. Canadian national laws and protections, such as those which are engrained in the Constitution were often cited as providing asylum seekers with rights, as were international treaties such as the 1951 Convention Relating to the Status of Refugees. Furthermore, the actors affirming the rights of asylum seekers tended to emphasize the fact that those arriving on foot from the United States have the same rights as any other asylum seekers in Canada, and that their method of entry into the country is irrelevant. The affirming of asylum seekers' rights in the Canadian newsprint media is important because it constructs these individuals as having a place within Canadian society, and challenges cases in which they are constructed as the Other. This is also done by demonstrating that asylum seekers have certain Constitutional rights just like everybody else in the country, by virtue of physically being on Canadian soil.

Articles which employed a positive framing of asylum seekers were found to be critical of the factors which are pushing individuals to cross irregularly into Canada, such as the Canada-US Safe Third Country Agreement. Furthermore, these articles were highly critical of Canada's federal government and its inaction in working to eliminate or at least minimize some of the risks which were being thrust upon asylum seekers by the Agreement. The federal government responded by arguing that it was still too early to tell whether Donald Trump or any 
of his policies were negatively impacting the safety of asylum seekers in the United States, and that the Agreement was thus still serving its purposes. In such articles, the Canadian federal government and the general Canadian population were constructed as being two separate entities with conflicting perceptions of the situation at hand.

Despite harshly criticizing the Agreement which pushed asylum seekers to cross irregularly, walking into the country at an unmarked border to claim asylum was still presented as being an entirely legitimate way of seeking asylum, and the individuals who chose to do so were constructed as being equally legitimate to those who enter by air and those who are resettled from abroad. This is significant because asylum seekers who cross into Canada irregularly are often seen as having 'jumped the queue' to get into the country, and are thus viewed as less legitimate than those who enter by other means. The border crossings, which often took place in isolated areas and in sub-zero temperatures, were presented as being large, but nonetheless necessary, risks which asylum seekers needed to undertake in order to have a chance at safety, as official channels were currently being blocked by the Canada-US Safe Third Country Agreement. Essentially, the findings of this study regarding the prevalence of positive portrayals of asylum seekers present a departure from past Canadian studies, in which they were primarily framed as constituting risks and security threats (Bradimore \& Bauder, 2011; Greenberg \& Hier, 2001; Lawlor, 2015).

While this study identified a departure from past studies, it also identified continuity. Although not the dominant way in which they were portrayed, asylum seekers continued to be framed in a negative manner by the newsprint media. In particular, they were frequently framed as 'risks' and threats to the security of Canada and the Canadian people, and as 'bogus' individuals who either are not worthy of asylum, or are seeking it in improper ways. Less 
frequently, they were also found to be portrayed as constituting a 'burden' on Canada and the Canadian people by virtue of their arrival, and as being culturally incompatible with Canadian values and way of life. These findings demonstrate that although a positive portrayal of asylum seekers is on the rise in comparison to the past, the negative attitudes towards asylum seekers which were uncovered in past studies are still prevalent in Canadian society today.

In order to successfully construct asylum seekers in these negative ways, certain terminology tended to be utilized to refer to them and to the border crossings they were making. Asylum seekers were regularly referred to 'border jumpers', 'border crossers', 'migrants', and 'illegal immigrants'. Such terminology is highly delegitimizing of their experiences because it calls into question whether or not they are indeed coming to Canada for the purposes of seeking asylum. For instance, the term 'border jumper' essentially lumps together all individuals who cross a national border irregularly. These could include legitimate asylum seekers who are fearing persecution and are entitled to certain legal and procedural rights, as well as criminals and gang members who are crossing the border for the purpose of drug trafficking. Furthermore, the terms 'migrants' and 'illegal immigrants' suggests that the motives of these individuals are unknown, and that they could just as easily be coming to Canada for economic purposes as for asylum-seeking purposes. Such terminology is used despite known statistics that almost all of the individuals who have crossed the border irregularly from the United States into Canada throughout the winter have gone on to file an asylum claim (Pedwell, 2017).

Similar delegitimizing and criminalizing terminology is used to refer to the border crossings which these individuals make as well. In particular, the phrases 'illegal crossings' and 'sneaking across the border' were utilized. Referring to the irregular crossings as 'illegal' is not necessarily incorrect, as they are prohibited by Canadian law. However, articles which do so fail 
to mention that this law is not enforced for individuals who enter for the purposes of claiming asylum; they are only held legally accountable for such crossings if their asylum claims are found to be illegitimate (Government of Canada, 2017). Furthermore, the suggestion that asylum seekers are 'sneaking' across the border works to construct them as security risks in the eyes of the Canadian public, although it is an incorrect claim. 'Sneaking', by definition, means, "behaving in a secret and dishonest manner" (Merriam-Webster Dictionary, 2017). The asylum seekers crossing irregularly into Canada, however, are not behaving in such a manner. It is acknowledged that these individuals are not trying to hide from border patrol officers nor enter the country without detection (The Canadian Press, 2017). Instead, they are immediately and willingly giving themselves up to the officers and to police. As such, this terminology misrepresents them and their intentions, for the purpose of constructing them as risks to Canada.

The main risk which asylum seekers were portrayed as posing is to the security of the border and to the integrity of the Canadian immigration system. Law enforcement was presented as losing the control which it previously held over the border and over who enters the country. However, border patrol officers and police have no less control now than they previously did. The fact is that individuals cannot be stopped from crossing the border irregularly, they can only be apprehended after they do so. Border patrol officers and police are regularly apprehending the asylum seekers after they cross, so they continue to exert the same amount of control that they previously did when the numbers of those crossing were lower than they are now. In terms of the integrity of the Canadian immigration system, asylum seekers are being represented as posing a risk to the trust which the Canadian people have in the system. Here, the concept of 'mutual security' emerges as a way of softening the criticism of asylum seekers. Many articles claim that if Canadians' trust in the immigration system is diminished, the security of future asylum seekers 
will be diminished as well because there will be less public and policy support for them. Such claims construct the Canadian people are being generous and tolerant in regards to immigration policy and the acceptance of newcomers, and that asylum seekers are testing that tolerance and taking advantage of 'Canadian kindness'.

The articles which presented concerns about the security of the Canadian border generally held similar critical views of the Canada-US Safe Third Country Agreement. Essentially, they called for the strengthening of the Agreement and for the closing of its 'loophole', which was blamed for the current rise in irregular migration into Canada. The 'loophole' refers to the fact that if asylum seekers from the US showed up at an official Canadian port of entry to make their claim, they would be denied entry and returned to the US (Government of Canada, 2002). By crossing irregularly at an unmarked border crossing, however, asylum seekers who manage to physically plant their feet on Canadian soil are permitted to make an asylum claim in Canada (Government of Canada, 2002). However, what such criticisms fail to realize is that once on Canadian soil, certain Canadian constitutional rights such as the right to due process apply to these individuals. Furthermore, once they are on Canadian soil America is not obligated to take these individuals back. As such, Canada must provide them with an asylum hearing if it wishes to be in compliance with both domestic and international laws.

The risks which asylum seekers were constructed as posing were further emphasized by fears about what the future holds. In particular, many articles expressed concerns that as the winter comes to an end and the weather warms, the number of asylum seekers entering the country would significantly increase. The construction of asylum seekers as an overtaking and uncontrollable force in many articles essentially constituted fear mongering. Terminology such 
as 'flood', 'surge', 'chaos', and 'crisis' was used to refer to the situation and to what would likely take place in the spring. However, much of this fear mongering was only possible due to the alarmingly frequent use of misleading and incomplete numerical figures and data which was provided as 'evidence' of impending doom. Historical variations in the numbers of asylum seekers crossing into Canada from the United States were masked in order to present the current figures as constituting a significant and worrying increase. Figures from certain years with lower rates of asylum seekers were provided, while figures from other years with higher rates were conveniently left out. Furthermore, several articles which were written on the topic of asylum seekers crossing into Canada from the United States would then provide figures of overall asylum claims in Canada, rather than just those from individuals who had entered on foot from the United States. These figures, presented in that particular context, have the effect of misleading the public into thinking that the issue of irregular migration from the United States is much larger than it is in reality.

Perhaps the most negative way in which asylum seekers were presented as posing risks is to the safety and security of Canadian citizens. Such a construction, rather than presenting them as a risk due to the number and way in which they are arriving, portrays them as risks on a personal level. It evokes assumptions of criminality, and of violent and dangerous behaviour. Many articles raised concerns about the fact that asylum seekers are released into the public while awaiting their asylum hearing, and argued that not detaining them during this period decreases the safety of Canada as a whole. While some articles did address these security concerns by explaining that all asylum seekers are security- and health-checked upon their arrival, and those with past criminal records are indeed detained, many articles did not. Furthermore, many of the articles which constructed asylum seekers as threats cited a Canadian 
poll which seems to suggest that the Canadian public largely agrees with such constructions. A recent poll found that about $40 \%$ of those polled believe that the presence of asylum seekers in Canada contributes to a decrease in overall safety (Nickel \& Ljunggren, 2017). This poll, and constructions of asylum seekers as posing security risks to Canadians, challenge Canadian national myths of kindness and acceptance of diversity, and suggest that Canadians may not be as different from Americans as other articles would like to suggest.

A lack of knowledge about the identity of those crossing the border into Canada was cited as the main reason for which asylum seekers were constructed as posing risks to Canadians. Rather than attempting to provide 'voice' to asylum seekers and share details which humanize them as a means of addressing this uncertainty, many articles used this lack of knowledge to construct asylum seekers as the risky Other, who belongs outside the realm of the Canadian nation rather than within it. The assumption that a lack of knowledge about an individual's identity means that they are inherently 'risky', demonstrates the prevalence of the concept of the Other as it relates to national identity. Individuals outside the borders of the nation are presented as risky, whereas those within the borders of the nation are not, simply by virtue of their physical location and not due to any greater knowledge about their identity.

These constructions of asylum seekers as inherently risky are in line with the findings of previous studies (Bradimore \& Bauder, 2011; Greenberg \& Hier, 2001; Lawlor, 2015). Individuals who arrive at Canada's borders for the purposes of claiming asylum are socially constructed as more 'risky' than those who arrive by plane and make their asylum claims inland, largely for the reason that their arrival is much more visible to the media. However, under Canadian immigration law, all refugees and asylum seekers, regardless of whether they cross the border on foot, arrive in Canada by boat or airplane, or are resettled from abroad, are considered 
to be equally legitimate (Government of Canada, 2017). Media discourses, however, do not always reflect this equality.

Not only are those asylum seekers who cross the border into Canada irregularly considered more risky than resettled refugees, the newsprint media was also found to construct them as being 'bogus' in several ways. Most frequently, they were presented as 'jumping the queue' to get into the country. Due to the fact that asylum seekers in the particular context of this study chose to enter Canada and claim asylum rather than waiting to be chosen by Canada, they were constructed as having 'jumped the queue' to get into the country. However, it must be mentioned that this 'queue' is entirely constructed, and does not exist in actuality. The Canadian refugee system has two main ways through which individuals can claim refugee status; the inland stream, and the resettlement stream (Government of Canada, 2017). Under Canadian law, both streams are considered equally legitimate, and asylum seekers from both streams are afforded equal rights and protections once their claims are accepted (Government of Canada, 2017). The equality of both streams is exemplified by the fact that during a refugee determination hearing, an individual's method of entry into the country does not need to be disclosed. Therefore, the concepts of 'proper' and 'improper' methods of entry and of 'legitimate' and 'illegitimate' asylum seekers are entirely socially constructed. Nevertheless, these constructions resonate with Canadians, and allow for the cultivation of opinions that these asylum seekers from the United States are being 'unfair' and are thus somehow less worthy of compassion and protection than those who are resettled from abroad.

This theme of the 'unfairness' of irregular border crossings was also found to emerge in relation to Canadian laws and the immigration system. The asylum seekers crossing the border into Canada from the United States were found to be constructed as bogus and illegitimate by 
being portrayed as abusing Canadian laws and Canadian generosity. Many articles claimed that asylum seekers view Canada as an 'easy target', and irregular border crossings as 'free tickets' into the country. Within this construction there were articles which considered the asylum seekers to be legitimately fleeing persecution, and those which viewed them as economic migrants. Both types of articles, however, presented the asylum seekers as taking advantage of Canada's 'generous' immigration laws and attitudes towards newcomers. The most frequent way in which they were presented as taking advantage of Canadian law was through accusations of 'asylum shopping' Essentially, asylum seekers are viewed as asylum shopping when they apply for asylum in more than one state, or in this case, when they are perceived as travelling through one or several 'safe' states in which they do not seek asylum, in order to do so in a subsequent state of their choice. Many articles accused asylum seekers of originally obtaining American visas for the purpose of eventually travelling to Canada and claiming asylum here. The CanadaUS Safe Third Country Agreement was created to deter such activities by asylum seekers, but does not apply to those who enter into the country at unmarked border crossings.

There were also those articles which entirely disputed the asylum seekers' status as persecuted individuals seeking protection in Canada. Asylum seekers are also presented as potentially being bogus, in the sense that they are not really refugees but economic migrants coming to Canada for the purposes of financial gain. While the possibility always exists that a small portion of individuals are economic migrants posing as asylum seekers, it is the job of the Immigration and Refugee Board, not the newsprint media, to determine so. Constructing an entire group of asylum seekers as illegitimate due to the fact that there is a possibility that some of their claims will be denied simply works to alienate them, and construct them as an Other. It is 
irresponsible as it damages public perceptions of these individuals, and can hinder their efforts at integration into Canadian society.

These constructions of asylum seekers are in line with past Canadian studies on the newsprint media's representation of asylum seekers, which questioned whether individuals claiming asylum truly needed protection or whether they had come to Canada for other reasons such as economic gain (Bradimore \& Bauder, 2011; Greenberg \& Hier, 2001; Lawlor, 2015). Although they are largely based off of misinformation and assumptions rather than evidence, these portrayals of asylum seekers as bogus and illegitimate are harmful because they can lead to widespread resentment towards asylum seekers and newcomers in general, if the public begins to feel as if Canada is being taken advantage of.

Public resentment towards asylum seekers is also fuelled by perceptions that one's own country or community is being disadvantaged or burdened by the arrival of outsiders. This study found that even when asylum seekers are accepted as legitimately facing persecution and requiring asylum, they are presented as being a burden upon Canadians. The main way in which the asylum seekers were presented as being a burden is to the various levels of government and settlement organizations, by virtue of their cost and resource needs. The cost and resource pressures placed upon the provincial and municipal governments of areas into which asylum seekers are directly crossing were presented as being particularly problematic. Law enforcement and emergency services were two service areas in which the needs of asylum seekers were presented as diverting attention from the needs of existing Canadian communities. Furthermore, the cost of the asylum seekers' various settlement needs, such as temporary and affordable housing, and legal representation, was presented as burdening certain towns and provinces. 
Additionally, asylum seekers were also presented as a constituting a burden to ordinary Canadian citizens. Many articles complained about the fact that most of the resources which asylum seekers require are funded by taxpayer dollars, which in their absence could have been used towards the benefit of Canadian citizens. Asylum seekers were also presented as inconveniencing Canadians living in border towns, by occasionally requiring the use of local public facilities for temporary accommodation, and by occasionally seeking help from residents during the nighttime. This framing of asylum seekers has a strong effect on constructing them as outsiders, and as the 'Other' who is placing financial burdens upon the communal resources of the national community.

However, while the increasing presence of asylum seekers was presented as being a burden upon certain areas, governments, and organizations, criticism of this was not directed at the asylum seekers themselves. Instead, much of the criticism was directed at the federal government for not providing enough help to the affected municipalities and provinces, and for not 'burden sharing' in what was argued to be a national issue. These criticisms of the government had the effect of framing the federal government as uninterested in providing assistance, and thus as failing to fulfill its responsibilities towards provincial and municipal governments. Furthermore, because the Trudeau government's actions were not viewed as living up to its positive and progressive rhetoric towards asylum seekers, this had the effect of lessening the media's criticism of asylum seekers. Instead, it constructed them as being victimized first by Trump's policies, and then further victimized by Trudeau's unfulfilled promises.

While the Trudeau government's stance towards refugees and asylum seekers emphasized the value of cultural diversity, this study found that there were also some articles which directly challenged such rhetoric. A small number of the analyzed articles constructed the 
asylum seekers crossing into Canada from the US as being incompatible with Canadian culture and values. These articles claimed that asylum seekers would have trouble integrating due to cultural differences which exist between Canada and their countries of origin. While some meant this in the sense that adaptability concerns such as 'language' exist, others outright claimed that asylum seekers were unwilling to integrate into Canadian society because their values were fundamentally different than Canadian values. The latter claims often emerged in articles which provided a platform for Conservative members of parliament to voice their opinions about the issue. Such rhetoric of incompatible values between asylum seekers and Canadians is a social construction. Asylum seekers are constructed as the foreign and hostile Other, as originally presented by Edward Said. The concept of 'Canadian values' goes to show how strong the concept of national community is, where elected officials can feel as though they can make the claim that all Canadians have shared values, whereas outsiders have ones which are fundamentally different. Although this construction was not frequent, it is notable for particularly this reason. During the time which this study was being conducted, this negative construction of asylum seekers was being vocally advanced by Conservative MP Kellie Leitch. The infrequency with which it emerged in the newsprint media, however, demonstrates that it did not exert enough influence to challenge the positive rhetoric of the Liberal government (Al-Solaylee, 2017).

The reason for such negative views being the minority rather than the majority may have to do with the fact that they challenge the core values of the Canadian national identity kindness, acceptance, and diversity - and instead affirm the rhetoric emerging from the US. Past studies have found that Canadian national identity formation takes place largely through selfdifferentiation from the US, and that the existence of America allows for the perpetuation of 
Canadian national myths by providing a construct of what Canadians are not. Until now, this process has taken place largely without any criticism or hostility towards the US, and even with admiration at times (Schwartz M. , 2010). This current study builds upon the body of literature dealing with Canadian media representations of America, as recent increases in irregular migration into Canada in the context of the Canada-US Safe Third Country Agreement stem directly from political developments in the United States. However, it presents a break from the findings of past studies, as America in general, and the Trump administration in particular, were found to be largely framed by the Canadian newsprint media as the morally inferior Other.

The United States was constructed by many articles as being a country which is no longer living up to its international obligations to asylum seekers, and a country in which the rights of asylum seekers were no longer being upheld. This representation of the United States worked to construct it as the Other in opposition to Canada, which was in turn constructed as a country in which the rights of asylum seekers continued to be protected. Therefore, Canadian national identity formation took place through self-differentiation from the United States. At the same time, the Canada-US Safe Third Country Agreement was constructed as no longer serving its purposes, given the political climate in the United States. Calls for its elimination supported constructions of Canada as a morally-superior country to the United States, and thus one which should take the lead in ensuring that this disadvantaging piece of legislation be repealed.

Furthermore, the inclusion of direct comments from asylum seekers and their advocates about their feelings of insecurity in the United States, while working to construct them as legitimate victims, also had the effect of constructing Canada as a safe haven in opposition to the United States. Canadian national myths of being the kinder, gentler, morally-superior North American nation were reinforced using this rhetoric. However, the Canadian federal government 
and the general Canadian population were constructed as being two separate entities with conflicting perceptions of the situation at hand. Government inaction in repealing or amending the Canada-US Safe Third Country Agreement was highly criticized, and presented as being in opposition to the demands of ordinary Canadians. By choosing to include the opinions of Canadians who were not satisfied with the treatment of asylum seekers and demanded improvements, Canadian national myths of kindness, and acceptance of difference were once again reinforced. A Canadian poll which challenged these myths with its findings that nearly half of Canadians would like to see irregular asylum seekers deported (Nickel \& Ljunggren, 2017), was not cited in many articles which sought to construct Canada's national identity along the lines of long-standing national myths.

While the context of this study is slightly different from past studies, in that now asylum seekers did not arrive in Canada all at once but are rather slowly trickling in across the border, the Canadian newsprint media's prevalence of employing the 'victim/human rights' framing can also likely be explained, at least partially, by Canada's attempt at differentiating itself from the United States. A recent study has found that for the first time in the 35 years in which the study the study has been conducted - and likely much longer than that - Canadians view America and Americans unfavourably (Dale, 2017). This likely has much to do with the current Trump administration, which the Canadian newsprint media has framed as contributing to the insecurity of asylum seekers in the United States. As such, the newsprint media has constructed Trump's America as the Other against which to construct a Canadian national identity, and against which what it means to be Canadian can be reaffirmed. The United States is framed as being a country which is no longer safe for asylum seekers and which is no longer living up to its global responsibilities - the exact opposite of the way in which Canada is being constructed. Such 
constructions allow for the reinforcement and perpetuation of Canadian national myths, and for the construction of identity that is entirely un-American.

\section{Conclusion}

This study set out to determine how the asylum seekers crossing the border into Canada from the United States were being framed by the Canadian newsprint media, in the context of the Canada-US Safe Third Country Agreement and Donald Trump's election. In doing so, it identified seven distinct framings of asylum seekers: 'victim/human rights', 'risk/security', 'agency/rights-bearing', 'bogus/illegitimate', 'burden', 'culturally incompatible' and 'beneficial to Canada'. These identified framings demonstrate the fact that there is not really a consensus of opinion in Canada about how the current issue should be perceived and what should be done about it. This is greatly due to the fact that a situation such as the one which Canada is experiencing now, where there has been a steady and consistent increase in irregular migration into the country over the past several months, is largely unprecedented (Keller, 2017). Canada is a country with a very fortunate geography when it comes to deterring irregular and illegal entry. The fact that it is surrounded by oceans on three sides makes it very difficult to reach. Furthermore, the fact that its fourth side is bordered by the United States - a country which has, until now, been the primary North American magnet for immigrants and refugees - means that it has historically not experienced too many issues when it comes to unauthorized entries. Since the implementation of the Canada-US Safe Third Country Agreement in 2002, it has encouraged some asylum seekers from the US to cross into Canada irregularly, due to the fact that they would be turned away if they attempted to claim asylum at an official border crossing. However, the number of individuals doing so has not been high enough, until now, to warrant much worry. 
Given the political changes which have taken place in the United States over the last six months, however, Canada's experience with irregular and illegal entry is changing. The current push factors of the Executive Orders, Trump, and xenophobia, coupled with the pull factor of the Trudeau government's welcoming rhetoric, is resulting in increasing numbers of irregular crossings (Government of Canada, 2017). Naturally, when an unprecedented situation takes place, many diverging opinions emerge.

The results of this study are in line with past Canadian studies in the sense that asylum seekers are still framed as risks and security threats, as well as bogus and illegitimate to a certain degree. Such framings affirm the fact that Canada as a society still has a long way to go when it comes to accepting refugees and asylum seekers as legitimate and important segments of the population. However, a positive and encouraging finding from this study is that these typical negative framings of asylum seekers have been overtaken in frequency by positive ones, notably the 'victim/human rights' framing, which legitimizes the experiences of asylum seekers and calls for compassion to be shown towards them. Furthermore, the frequent calls for the Canada-US Safe Third Country Agreement to be rescinded are encouraging because the majority of them are based on humanitarian considerations rather than on border security concerns.

This partial departure from past studies likely has much to do with Canada's current perception of the United States under the Trump administration. Canada has historically been found to form its national identity in opposition to the United States - even when it viewed the United States in a positive light (Melvin, 2005; Schwartz M. , 2010; Winter, 2007). Now that Canadians have been found to view America negatively (Dale, 2017), attempts of selfdifferentiation can logically be expected to be even more pronounced. One dominant way in which Canadians have found to be able to differentiate themselves from Americans is through 
the media's representation of asylum seekers impacted negatively by Trump's policies. As Donald Trump's administration cracks down on immigration and takes rights from refugees and asylum seekers away, the Canadian newsprint media is shifting its historically negative framing of asylum seekers and immigration in general, further over to the positive side. The reason for this is not that Canada and Canadians are inherently better than their American counterparts in any way, but recent political developments are allowing for the perpetuation of that belief by the Canadian newsprint media. Positive representations of asylum seekers by the Canadian newsprint media, although by no means the sole way in which they are being portrayed, are more frequent than they were in the past. As such, they serve as a means of differentiating Canada from America, and reinforcing long-held Canadian national myths of being the kinder, gentler, morally-superior North American nation. 


\section{APPENDIX}

List of Analyzed Newsprint Articles

1. Annett, E. (2017, February 19). Asylum seekers from the US: A guide to the saga so far, and what Canadians think of it. The Globe and Mail.

2. Banerjee, S. (2017, February 20). Montreal becomes sanctuary city after unanimous vote; rights' groups call it symbolic. National Post.

3. Barutciski, M. (2017, March 2). Michael Barutciski: Enough with this silly 'loophole' at the border: Mr. Trudeau, we need a clear policy, now. National Post.

4. Clark, C. (2017, February 21). A solution to Canada's refugee surge is no easy feat. The Globe and Mail.

5. Clark, C. (2017, March 27). Clickbait policies from Tory leadership hopefuls won't stop asylum seekers. The Globe and Mail.

6. Clark, C. (2017, January 31). Trudeau government plays waiting game amid uncertainty of Trump era. The Globe and Mail.

7. Coyne, A. (2017, February 21). A crisis is coming: If this many cross the US border in February, how many will come by June? National Post.

8. Coyne, A. (2017, March 8). Andrew Coyne: Assumptions behind immigration rage don't stand up to scrutiny. National Post.

9. Curry, B. (2017, February 21). Canada's border agencies shift staff to deal with illegal crossings. The Globe and Mail.

10. Dhillon, S. (2017, March 28). Border-crosser arrests drop steeply in BC, rise elsewhere. The Globe and Mail.

11. Dhillon, S. (2017, January 31). Quebec City mosque shooting a wake-up call for Canada, BC lawyer says. The Globe and Mail.

12. Dhillon, S. (2017, February 15). Two arrested ub Surrey, BC after alleged illegal border crossing. The Globe and Mail.

13. Dhillon, S., \& Fine, S. (2017, February 12). Quebec and Manitoba see influx of asylum seekers crossing US border. The Globe and Mail.

14. Drinkwater, R., \& Lowrie, M. (2017, February 12). RCMP says 21 people arrested for illegally crossing border at Emerson, Manitoba. National Post.

15. Galloway, G., \& Zilio, M. (2017, January 31). Despite Trump ban, Canada won't increase refugee quotas . The Globe and Mail.

16. Galvin, T. (2017, February 8). Terry Galvin: Canadians are not as good as we pretend (but we're still pretty good). National Post. 
17. Galvin, T. (2017, February 1). Terry Galvin: The very least Trudeau could do is get out of the way. But he won't. National Post.

18. Giovannetti, J. (2017, February 27). Following the Midwest Passage: Asylum seekers take cold journey to Manitoba via Trump's America. The Globe and Mail.

19. Giovannetti, J. (2017, February 19). Influx of refugees fleeing US is putting Ottawa to the test. The Globe and Mail.

20. Hamilton, G. (2017, February 17). Cab rides to the border: Refugee claimants 'gouged' to escape US into Canada. National Post.

21. Keller, T. (2017, February 23). Canada has never had a real migrant crisis. Trump may have just changed that. The Globe and Mail.

22. Krugel, L. (2017, February 19). 'He was anxious, he was scared': US woman shocked friend walked to Canada after asylum claim rejected. National Post.

23. Krugel, L. (2017, February 19). US woman shocked asylum-seeking friend walked to Canada. The Globe and Mail.

24. Kurl, S., \& Korzinski, D. (2017, February 27). Tolerance for refugees has limits - even in Canada. The Globe and Mail.

25. Lambert, S. (2017, March 8). 19 asylum-seekers cross border in fierce Manitoba blizzard . The Globe and Mail.

26. Lambert, S. (2017, February 14). Asylum-seekers speak of dangerous voyage that led them to Canada. The Globe and Mail.

27. Lambert, S. (2017, March 4). Goodale visits Manitoba border-crossing site; suggests more resources from Ottawa. The Globe and Mail.

28. Lambert, S. (2017, February 23). Manitoba Premier Brian Pallister urges Ottawa to act on asylum-seekers jumping border. The Globe and Mail.

29. Lambert, S. (2017, February 21). Provinces, Ottawa require united refugee approach: Manitoba premier. The Globe and Mail.

30. Leblanc, D. (2017, March 27). Conservative leadership camps ratchet up plans to stop asylum seekers. The Globe and Mail.

31. Leblanc, D. (2017, March 7). Ottawa braces for rise in asylum seekers fleeing US. The Globe and Mail.

32. Leblanc, D. (2017, March 2). RCMP not charging asylum seekers for illegal entry into Canada. The Globe and Mail.

33. Leuprecht, C. (2017, March 29). More border resources for migrants is not a solution. The Globe and Mail.

34. Levitz, S. (2017, March 5). Cabinet set to map out scenarios for dealing with asylum seekers illegally crossing border. The Globe and Mail. 
35. Levitz, S. (2017, March 6). Federal government to review details of new Trump immigration ban. The Globe and Mail.

36. Levitz, S. (2017, March 21). Illegal border crossers arrested this year nearly half of all caught in 2016. The Globe and Mail.

37. Levitz, S. (2017, April 19). RCMP stopped 887 asylum seekers from illegally entering Canada last month. The Globe and Mail.

38. Levitz, S. (2017, April 19). RCMP stopped 887 people trying to illegally enter Canada in March - nearly tripling January numbers. National Post.

39. Levitz, S. (2017, March 20). Too soon to put Canadian price tag on Trump's immigration overhaul: officials. The Globe and Mail.

40. Lowrie, M. (2017, April 23). Border towns quietly mobilizing to help asylum-seekers coming to Canada. The Globe and Mail.

41. Malo, S. (2017, March 22). Number of asylum seekers crossing into Canada soars. The Globe and Mail.

42. Mason, G. (2017, February 9). How Canada can take Trump's refugees. The Globe and Mail.

43. Mason, G. (2017, March 14). Manitoba Premier Pallister calls on Trudeau to raise asylum issues with Trump. The Globe and Mail.

44. McParland, K. (2017, February 23). Kelly McParland: If the Liberals drop the migrant ball, Candians will lose patience quickly. National Post.

45. Moore, O. (2017, February 4). Protesters march across Canada against Islamophobia and Trump's immigration ban. The Globe and Mail.

46. National Post View. (2017, February 24). National Post View: Preparing for a border crisis is the most important job the Liberals have now. National Post.

47. Nickel, R., \& Ljunggren, D. (2017, March 20). Almost half of Canadians want illegal border crossers deported: poll. The Globe and Mail.

48. Nixon, D. (2017, February 7). Manitoba town pleads for federal help with refugee influx. The Globe and Mail.

49. Nixon, D. (2017, February 9). Manitoba town to receive help in handling refugee influx. The Globe and Mail.

50. Nixon, D. (2017, February 13). Winnipeg steps up with aid for refugees denied US asylum. The Globe and Mail.

51. Perkel, C. (2017, January 30). Protesters decry Trump's ban in Ottawa, Toronto. The Globe and Mail.

52. Perreaux, L. (2017, February 20). Fearing Trump, asylum seekers travel across USCanada border, regardless of risks. The Globe and Mail. 
53. Porter, C., Levin, D., \& Austen, I. (2017, February 11). 'Trump was going to deport me': Migrants are losing fingers to frostbite while fleeing to Canada. National Post .

54. Quan, D. (2017, March 13). Caught at Canada's border: What happens once asylum seekers cross irregularly. National Post.

55. Quan, D. (2017, March 2). CBSA union president says border is like 'Swiss cheese,' calls for patrol force. National Post.

56. Quan, D. (2017, April 19). Human smuggling charges for woman discovered driving nine refugee claimants near US border. National Post.

57. Quan, D. (2017, April 20). Husband of Regina woman accused of human smuggling arrested along with another Canadian. National Post.

58. Quan, D. (2017, February 20). Liberal government 'testing the limits' of Canadians' attitudes to refugees: poll. National Post.

59. Quan, D. (2017, February 7). Manitoba town's generosity is tested amid spike in asylum seeking 'border jumpers' since Trump elected. National Post.

60. Saunders, D. (2017, February 25). Canada has a border problem. Here's how to fix it. The Globe and Mail.

61. Selley, C. (2017, February 17). Chris Selley: As Trump's refugees stream into Canada, will our immigration policies hold up? National Post.

62. Stone, L. (2017, April 2). Illegal border crossings at forefront of Tory leadership debate. The Globe and Mail.

63. The Canadian Press. (2017, March 20). 29 asylum-seekers cross border into Manitoba over the weekend. The Globe and Mail.

64. The Canadian Press. (2017, February 14). Four people arrested for illegally crossing US border into Quebec: RCMP. The Globe and Mail.

65. The Canadian Press. (2017, March 8). 'Not pretty out there': Nineteen asylum-seekers cross border in Manitoba blizzard with $80 \mathrm{~km} / \mathrm{h}$ winds. National Post.

66. The Canadian Press. (2017, March 9). Ottawa hasn't replied to request for aid to handle asylum seekers: Manitoba Premier. The Globe and Mail.

67. The Canadian Press. (2017, February 26). Ottawa not convinced refugee surge constitutes a trend. The Globe and Mail.

68. The Canadian Press. (2017, February 11). RCMP says 21 people arrested for illegally crossing border at Manitoba town. The Globe and Mail.

69. The Canadian Press. (2017, February 19). Two Tory MPs call on Ottawa to stop illegal Canada-US border crossings. The Globe and Mail.

70. The Canadian Press. (2017, February 23). UN monitoring asylum seekers crossing Canada-US border. The Globe and Mail. 
71. The Canadian Press. (2017, March 5). Under pressure, Cabinet braces for discussion on border-jumpers that planned to cross long before election. National Post.

72. The Globe and Mail. (2017, April 3). Are we headed for a refugee crisis on our border? Ottawa needs to tell us. The Globe and Mail.

73. The Globe and Mail. (2017, February 21). Globe editorial: Is Canada ready for Donald Trump's refugee crisis? The Globe and Mail.

74. Thompson, N. (2017, February 12). Lawyers urge Ottawa to make changes to Safe Third Country Agreement. The Globe and Mail.

75. Thompson, N. (2017, February 5). Trudeau should 'lift the cap' on refugee sponsorships in wake of Trump immigration order: protesters. National Post.

76. Watson, W. (2017, March 13). William Watson: Every country has a tipping point on border crossers. Do we know Canada's? National Post.

77. Weeks, C. (2017, February 6). Canadian Paediatric Society speaks out against Trump immigration order. The Globe and Mail.

78. Wente, M. (2017, February 27). Trudeau needs to have a Merkel moment. The Globe and Mail.

79. Woo, A. (2017, April 26). Cash-strapped BC organizations seek to accomodate refugee influx. The Globe and Mail.

80. Woo, A. (2017, April 19). RCMP charge Saskatchewan woman with human smuggling. The Globe and Mail.

81. Yakabuski, K. (2017, February 22). Denis Coderre's needless test of Canadian tolerance. The Globe and Mail.

82. Zilio, M. (2017, February 1). Advocates, lawyers mull court challenge to Canada's refugee pact with US. The Globe and Mail.

83. Zilio, M. (2017, February 8). Trudeau concerned about refugee influx in Manitoba border town. The Globe and Mail. 


\section{References}

Al-Solaylee, K. (2017, January 31). Anti-Muslim hate has been in Canada - and our politics long before the violence. The Globe and Mail.

Amnesty International Canada; Canadian Council for Refugees. (2017). Contesting the designation of the US as a safe third country.

Arbel, E., \& Brenner, A. (2013). Bordering on failure: Canada-US border policy and the politics of refugee exclusion. Harvard Immigration and Refugee Law Clinical Program.

Berger, P., \& Luckmann, T. (1966). The social construction of reality: A treatise in the sociology of knowledge. The Penguin Press.

Berger, R. (2013). Now I see it, now I don't: Researcher's position and reflexivity in qualitative research. Qualitative Research, 219-234.

Bradimore, A., \& Bauder, H. (2011). Mystery ships and risky boat people: Tamil refugee migration in the newsprint media. Canadian Journal of Communication, 637-661.

Canadian Council for Refugees. (2017, February). Refugees entering from US and Safe Third Country: FAQ. Retrieved from Canadian Council for Refugees: http://ccrweb.ca/en/refugees-entering-us-and-safe-third-country-faq

Cutler, C. (2004). The US-Canada Safe Third Country Agreement: Slamming the door on refugees. ILSA Journal of International \& Comparative Law, 121-142.

Dale, D. (2017, June 26). Under Trump, a majority of Canadians dislike the U.S. for the first time in 35 years, likely much longer. The Toronto Star. 
Fryberg, S., Stephens, N., Covarrubias, R., Markus, H., Carter, E., Laiduc, G., \& Salido, A. (2011). How the media frames the immigration debate: The critical role of location and politics. Analyses of Social Issues and Public Policy, 1-17.

Galbin, A. (2014). An introduction to social constructionism. Social Research Reports, 82-92.

Government of Canada. (2002, December 5). Final Text of the Safe Third Country Agreement. Retrieved from Government of Canada: http://www.cic.gc.ca/english/department/lawspolicy/safe-third.asp

Government of Canada. (2017). Asylum claims and interceptions: Monthly report. Ottawa: Government of Canada.

Government of Canada. (2017, March 3). Claiming asylum in Canada - what happens?

Retrieved from Government of Canada: https://www.canada.ca/en/immigration-refugeescitizenship/news/2017/03/claiming_asylum_incanadawhathappens.html

Government of Canada. (2017, July 12). Constitution Act, 1982. Retrieved from Canada: http://laws-lois.justice.gc.ca/eng/Const/page-15.html\#h-42

Government of Canada. (2017, April 3). How Canada's refugee system works. Retrieved from Government of Canada: http://www.cic.gc.ca/english/refugees/canada.asp

Greenberg, J., \& Hier, S. (2001). Crisis, mobilization and collective problematization: "Illegal" Chinese migrants and the Canadian news media. Journalism Studies, 563-583.

Hannah, D., \& Lautsch, B. (2011). Counting in qualitative research: Why to conduct it, when to avoid it, and when to closet it. Journal of Management Inquiry, 14-22. 
Harvard Law School. (2017). The impact of President Trump's Executive Orders on asylum seekers.

HILSC. (2017, July 6). Information about the travel ban. Retrieved from Houston Immigration Legal Services Collaborative: http://www.houstonimmigration.org/travelban/

House of Commons. (2014, February 11). Bill C-43. Retrieved from Parliament of Canada: http://www.parl.ca/DocumentViewer/en/41-2/bill/C-43/first-reading/page-4

Hsieh, H.-F., \& Shannon, S. (2005). Three Approaches to Qualitative Content Analysis. Qualitative Health Research, 1277-1288.

Keller, T. (2017, February 23). Canada has never had a real migrant crisis. Trump may have just changed that. The Globe and Mail.

Lawlor, A. (2015). Framing immigration in the Canadian and British news media. Canadian Journal of Political Science, 329-355.

Macklin, A. (2005). Disappearing refugees: Reflections on the Canada-US Safe Third Country Agreement. Columbia Human Rights Law Review, 365-426.

Melvin, C. (2005). Cross-cultural representations: The construction of "America" after September 11th in English Canadian, Quebec, and French print media. School of Translation and Interpretation, 1-113.

Merriam-Webster Dictionary. (2017). Sneaking. Retrieved from Merriam-Webster: https://www.merriam-webster.com/dictionary/sneaking 
Nickel, R., \& Ljunggren, D. (2017, March 20). Exclusive: Almost half of Canadians want illegal border crossers deported - Reuters poll. Retrieved from Reuters: http://www.reuters.com/article/us-canada-immigration-poll-exclusive-idUSKBN16R0SK

Paperny, A., \& Lampert, A. (2017, August 17). Canada sees 'unsustainable' spike in asylum seekers at US border. Retrieved from Reuters: https://ca.reuters.com/article/topNews/idCAKCN1AX1PO-OCATP

Pedwell, T. (2017, July 21). Illegal border crossings shift from Manitoba to Quebec: June stats. CTV News.

Said, E. (1978). Orientalism. Pantheon Books.

Sarbit, L. (2003). The reality beneath the rhetoric: Probing the discourses surrounding the Safe Third Country Agreement. Journal of Law and Social Policy, 139-158.

Schuster, L. (2003). Common sense or racism? The treatment of asylum seekers in Europe. Patterns of Prejudice, 233-256.

Schwartz, D. (2015, October 4). Canada's Refugees by the Numbers: the Data. CBC News.

Schwartz, M. (2010). Like "Us" or "Them"? Perceptions of the United States on the CBC-TV National News Service in the 1960s. Journal of Canadian Studies, 118-153.

Stevenson, V. (2017, August 3). Why are thousands of Haitians streaming into Canada from the US? CBC News.

The Canadian Press. (2017, February 11). RCMP say 21 people arrested for illegally crossing border at Manitoba town. The Globe and Mail. 
The Council of Canadians. (2014). Cruel and unusual: The Conservatives' many-sided assault on refugee and migrant health. The Council of Canadians.

The White House. (2017, January 27). Executive order: Protecting the nation from foreign terrorist entry into the United States. Retrieved from The White House: https://www.whitehouse.gov/the-press-office/2017/01/27/executive-order-protectingnation-foreign-terrorist-entry-united-states

Vermont Law School. (2005). Domestic silence: How the US-Canada Safe third Country Agreement brings new urgency to the need for gender-based asylum regulations. Vermont Law Review, 1045-1078.

Willig, C. (2013). Introducing qualitative research in psychology. McGraw-Hill Education.

Winter, E. (2007). Neither 'America' nor 'Quebec': Constructing the Canadian multicultural nation. Nations and Nationalism, 481-503.

Zoppo, A., \& Santos, A. (2017, July 24). Here's the full list of Donald Trump's Executive Orders. NBC News. 